\title{
Efficacies of repurposing chloroquine analogues for the treatment of COVID-19: Facts and myths
}

\author{
Md. Abdul Alim Al-Bari ${ }^{1}$ \\ ${ }^{1}$ University of Rajshahi
}

April 28, 2020

\begin{abstract}
The emergence of coronavirus disease 2019 (COVID-19) is caused by the 2019 novel coronavirus (2019-nCoV). The 2019-nCoV first broke out in Wuhan and subsequently spread worldwide owing to its extreme transmission efficiency. The fact that the COVID-19 cases and mortalities are reported in globally and the WHO has declared this outbreak as the pandemic. The international health authorities have focused on rapid diagnosis and isolation of patients as well as the search for therapies able to counter the disease severity. Due to the lack of a known efficient therapy and public health emergency, repurposing drugs chloroquine (CQ) analogues appear to be the best tool against 2019-nCoV infection. These analogues have shown potential efficacy to inhibit 2019-nCoV in vitro that leads to focus in several new trials. This review discusses the possible effective roles and mechanisms of CQ analogues for interfering with the 2019-nCoV replication cycle and infection.
\end{abstract}

\section{Introduction}

Coronaviruses (CoVs) are members of the family Coronaviridae in the order Nidovirales.$^{1}$ CoVs are enveloped, single-stranded, positive-sense RNA viruses having the largest genome among RNA viruses ( $\left.{ }^{\sim} 32 \mathrm{~kb}\right) .^{2}$ $\mathrm{CoVs}$ are spreading worldwide and naturally infect a variety of species. Earlier, six CoVs have been identified that mostly cause respiratory and central nervous system (CNS) pathologies in humans. Human coronavirus $229 \mathrm{E}$ (HCoV-229E) and HCoV-OC43 classified in the genus of Alpha-coronavirus and Beta-coronavirus lineage 2a member respectively, usually cause common colds during the winter and early spring. ${ }^{3,4} \mathrm{HCoV}-\mathrm{NL} 63$ (Alpha-coronavirus lineage $1 \mathrm{~b}$ member) is responsible for causing croup in children and outcomes in more severe clinical features than those of $\mathrm{HCoV}-229 \mathrm{E}$ or HCoV-OC43. ${ }^{4-6} \mathrm{HCoV}-\mathrm{HKU} 1$ (Beta-coronaviruslineage 2a member) is associated with bronchiolitis and pneumonia. ${ }^{7}$ In 2003, a lethal zoonotic CoV infection called severe acute respiratory syndrome (SARS) was reported to outbreak in China and associated with SARS-CoV-1 (Beta-coronavirus lineage 2b member). ${ }^{8}$ In 2012, a SARS-like disease re-emerged and the causative agent was identified as Middle East respiratory syndrome CoV (MERS-CoV, as classified in Beta-coronavirus lineage 2c).$^{9,10}$ All of the human CoVs are infectious respiratory pathogens that also cause neurological diseases. ${ }^{11-13}$ Thus, all of the CoVs are thought to be responsible for respiratory tract infections and neurological pathologies in a similar way to other known neuroinvasive viruses like measles virus or human immunodeficiency virus (HIV). ${ }^{14}$ Recently, the seventh human $\mathrm{CoV}$ called severe acute respiratory syndrome coronavirus 2 (SARS-CoV-2) as officially named as 2019 novel coronavirus (2019-nCoV) a novel Beta-coronavirus emerged in the Chinese city of Wuhan in December 2019 as being responsible for respiratory infection including pneumonia. ${ }^{15,16}$

Depending on drastic outbreak measures and the worldwide spreading because of its probable high transmission efficiency, 2019-nCoV is also known as SARS coronavirus 2 (SARS-CoV-2). Phylogenetic analysis of this virus indicates that it is different $\left({ }^{\sim} 80 \%\right.$ nucleotide identity) but related to SARS-CoV- $1 .{ }^{17}$ In clinical pathology, 2019-nCoV is responsible for respiratory infections including asymptomatic carrier state, acute respiratory disease (ARD) and pneumonia with a mortality rate estimated about $2 \%-2.5 \%$, increasing with 
age and the existence of underlying diseases. ${ }^{18}$ Since the $2019-\mathrm{nCoV}$ has transmitted with high frequency, and multiple countries have confirmed the coronavirus disease 2019 (COVID-19) cases, ${ }^{19-21}$ the World Health Organization (WHO) has announced a new name as pandemic disease on March $12^{\text {th }} 2020 .{ }^{22}$

COVID-19 is now public health emergency of international concern. Currently, the world is threatened by the COVID-19 pandemic because the number of people diagnosed with 2019-nCoV infection is increasing day by day. Unfortunately, to date, no known validated specific, efficient therapies have approved by drug regulatory agencies for the treatment of $2019-\mathrm{nCoV}$ infection. Scientists are endeavouring to discover drugs or vaccines to treat this disease, but it takes much more times. Thus, the researchers and medical teams have focused on repurposing FDA-approved drugs to treat the most vulnerable and severe cases of this infection. ${ }^{23}$ Drug repurposing is an effective way to quickly identify therapeutic drug with a known safety profile to treat an emerging disease. As these aspects, chloroquine (CQ) analogues, traditionally used to treat malaria, are necessary particular attention for repurposing for COVID-19 treatment because of their broad-spectrum antiviral effects. CQ analogues have been shown to inhibit effectively the viral replication including SARS-CoV and MERS-CoV. ${ }^{24-26}$ Recently, CQ is found to inhibit 2019-nCoV in vitro and its hydroxylated form, hydroxychloroquine (HCQ) has been proposed as a possible therapy to treat patients infected with 2019-nCoV. ${ }^{26,27}$ Based on in vitro results and clinical studies in several Chinese hospitals, a great deal of effort has been made to find effective drugs against the virus in China. ${ }^{28}$ On February 17, 2020, the State Council of China provided a briefing news indicating that the superiority, marked efficacy and acceptable safety of CQ analogue in treating COVID-19 in terms of reduction of exacerbation of pneumonia, duration of symptoms and delay of viral clearance. ${ }^{29}$ These results have directed in China to include CQ analogue in the recommendations regarding the prevention and treatment of COVID-19 pneumonia. ${ }^{29-31}$

\section{Repurposing chloroquine (CQ) analogues: A hurdling therapy from malaria to viral diseases}

Nobel laureate (1988) James Black, the renowned pharmacologist precisely defines the repositioning approach as "the most fruitful basis for the discovery of a new drug is to start with an old drug". The traditional drug discovery is an indeed challenging field in terms of rising and unsustainable costs (several hundred million dollars expenses from an idea to a marketed drug), and time-consuming tasks (an average of 15 years), with a high failure rate. ${ }^{32}$ Pharmaceutical industries have experienced to an annual decrease in return on investment ${ }^{33}$ and health care authorities have faced the prime challenge in their existence for financial sustainability fuelled by the costs of prescription drugs. ${ }^{34}$ In this context, drug repurposing (scanning the existing pharmacopoeia for new therapeutic uses or indications) appears as a new value proposition for the industry, patients and payers. ${ }^{35,36}$ Moreover, the repurposing approach may overcome many problems associated with producing new drugs by the traditional method because of their known pharmacokinetics, pharmacodynamics, and safety profiles and approved by the regulatory agencies, for example the Food and Drug Administration, USA (FDA) and this knowledge accelerates the evaluation of the drug in clinical trials. 37,38

Historically, one of the well-known repurposing victory stories is the (re)use of CQ analogues. CQ and its structural analogues such as HCQ, pamaquine, plasmoquine, primaquine or mefloquine have been used for decades as the primary and most successful drugs against malaria. These analogues still remain the drug of choice for malaria chemotherapy because they are inexpensive, orally available, well tolerated and effective drugs and low toxicity in humans. ${ }^{39}$ Concomitant with the emergence of CQ-resistant Plasmodium strains and a subsequent decrease in the use as antimalarial drugs, new potential uses of the cheap and existing analogues have also been investigated. ${ }^{39}$ Due to their immunomodulatory effects, these analogues have been used as secondary drugs to treat a variety of chronic autoimmune diseases (e.g., rheumatoid arthritis, systemic lupus erythematosus etc.), tumors and nonmalarial infections (Table 1). ${ }^{39}$ Recently, several efforts have been made to identify effective, inexpensive and universally available antiviral agents (Table 1). In these aspects, the CQ analogues have been suggested as such antiviral agents by inhibiting several viral replications. ${ }^{25,40}$ For examples, these analogues are explored against filoviral infections including influenza A and B, SARS coronavirus, hepatitis A virus and the Borna disease and other viral diseases such as HIV and dengue, MERS virus and chikungunya virus (CHIKV) which are associated with replication cycle and inflammation. ${ }^{41}$ Thus, 
the repurposing approach of CQ analogues has been successfully passed by serendipitous discovery or clinical observation.

\section{Antiviral activities of chloroquine (CQ) analogues}

The antiviral activity of CQ analogues has been identified since the late 1960's. ${ }^{41} \mathrm{CQ}$ analogues suppress the growth of versatile viruses (Table 2) in cell cultures in vitro e.g., the SARS coronavirus. ${ }^{42}$ These analogues have been reported to possess antiviral activity against a wide range of RNA viruses ${ }^{43,44}$ such as HIV, hepatitis A virus, hepatitis $\mathrm{C}$ virus, influenza A H5N1 virus, ${ }^{45}$ influenza A and B viruses, CHIKV ${ }^{46}$ Dengue virus ${ }^{47}$ Crimean-Congo hemorrhagic fever virus, ${ }^{48}$ Ebola virus, Zika virus, Hendra and Nipah viruses. ${ }^{41}$

In case of acute infection like CHIKV, although CQ shows promising antiviral activity in vitro ${ }^{46,49}$ but is shown to augment alphavirus replication in various animal models in vivo.$^{50,51} \mathrm{In}$ a nonhuman primate model of CHIKV infection, CQ treatment is also shown to exacerbate acute fever and delay the cellular immune response, leading to an incomplete viral clearance. ${ }^{50} \mathrm{~A}$ clinical trial conducted during the chikungunya outbreak in 2006 in Réunion Island demonstrates that oral CQ treatment is powerless to improve the course of this acute disease ${ }^{51}$ and that chronic arthralgia on day 300 post illness is more frequent in treated patients than in the control group. ${ }^{50}$ Altogether, the evaluation of previous data suggests that CQ analogues have lack of capacity to inhibit acute virus infection successfully in humans. CQ analogue has also been assessed in chronic viral diseases. Its use in the treatment of HIV-infected patients has been considered in conclusive ${ }^{52}$ and the drug has not been included in the panel recommended for HIV treatment. The only modest effect of CQ in the therapy of human virus infection is found for chronic hepatitis C. ${ }^{53,54}$ This is not enough to include CQ in the standardised therapeutic protocols for hepatitis C patients. Interestingly, a line of evidence indicates that the antiviral activity of these analogues is found in mice against a variety of viruses, including human coronavirus OC43, ${ }^{55}$ Zika virus ${ }^{56}$ and influenza A H5N1. ${ }^{45}$ However, CQ is also active ex vivo but not in vivo in the case of Ebola virus in mice, ${ }^{41}$ and influenza virus ${ }^{57}$ in ferrets. Moreover, CQ analogue is incapable to prevent influenza infection in a randomized, double-blind, placebo-controlled clinical trial ${ }^{41}$ and has no effect on Dengue-infected patients in a randomized controlled trial in Vietnam. ${ }^{58}$ Thus, the antiviral properties of CQ analogues described in vitro have sometimes been established during treatment of virus-infected patients but have not always been reproduced in clinical trials depending on several factors such as the severity of disease, the concentration of CQ analogue used, the duration of treatment and the clinical team in charge of the trials.

\section{Potentiality of chloroquine (CQ) analogues against coronaviruses including 2019-nCoV}

$\mathrm{CQ}$ analogues have broad spectrum of antiviral action against coronaviruses (Table 2). For example, the potential therapeutic benefits of CQ analogues are notably reported for SARS-CoV- $1 .{ }^{25,55} \mathrm{CQ}$ analogue is also reported to inhibit in vitro the replication of HCoV-229E in epithelial lung cell cultures. ${ }^{59}$ Also, the administration of CQ through the mother's milk averts lethal infections of HCoV-O43 coronavirus in newborn mice. ${ }^{41}$ Moreover, a strong antiviral effect of CQ is exhibited on a recombinant HCoV-O43 coronavirus in vitro ${ }^{60}$ Although CQ analogue is reported to be active against MERS-CoV in vitro ${ }^{61}$ this observation remains controversial. ${ }^{62}$ 2019-nCoV (SARS-CoV-2) is closely relative to SARS-CoV-1 due to the occurrence of cell entry and replication cycle through the endolysosomal pathway. ${ }^{43,63}$ Thus, it makes sense in a publichealth emergency situation and the absence of any known efficient therapy, it is indispensable to investigate the possible antiviral effects of these analogue against 2019-nCoV. A recent paper indicates that CQ analogue is found to inhibit the growth of $2019-\mathrm{nCoV}$ in vitro, ${ }^{27}$ and suggests these drugs be assessed in human patients suffering from COVID-19. ${ }^{64}$ According to preliminary reports, ${ }^{29,31}$ the National Centre for Biotechnology Development (NCBD), China designated that $\mathrm{CQ}$ analogue is one of the most promising drugs against the new 2019-nCoV coronavirus that causes COVID-19. These findings have been supported that approximately one-hundred 2019-nCoV infected patients treated with CQ analogue experienced a more rapid decline in fever and improvement of lung computed tomography (CT) images and required a shorter time to recover compared with control groups, with no obvious serious adverse effects. Thus, the Chinese medical advisory board and authorities have suggested CQ analogue inclusion in the 2019-nCoV treatment guidelines. As a result, CQ is probably the first molecule to be used in China and abroad on the front line for the treatment 
of severe 2019-nCoV infections. Although the long-term use of these analogues in nonmalarial therapy such as rheumatoid arthritis or lupus demonstrates some severe adverse effects such as macular retinopathy and cardiomyopathy depending on the cumulative doses, ${ }^{65,66}$ everyone concerns only the current world-wide lifethreatening emergency situation. The adverse effects of CQ analogue therapy remain to be performed for 2019-nCoV-infected patients. However, CQ analogues are currently among the best existing drugs to impact the severity of 2019-nCoV infections in humans.

\section{Antiviral mechanism action of chloroquine (CQ) analogues}

Although the mechanism of action of CQ analogue against coronaviruses has not been completely elucidated, the increasing evidences suggest that the entry, replication and infection of several emerging viruses such as Ebola, Marburg, dengue, CHIKV, HIV etc. are highly dependent on autophagy process particularly autolysosomal stage or lysosomal acidification. ${ }^{40,43}$ By alkalizing the autolysosome or neutrality of acidic $\mathrm{pH}$ in acidic vesicles like lysosomes, $\mathrm{CQ}$ analogue hampers the low-pH-dependent steps of these viral entry and replication, including fusion and uncoating into the cytoplasm of susceptible cells and thereby abrogate their infections. ${ }^{25,44}$ Findings from previous studies have suggested that the analogue may inhibit the coronavirus through similar steps. The analogue can not only change the $\mathrm{pH}$ at the surface of cell membrane but also inhibit the autophagosome-lysosome fusion in autophagy process. The analogue also inhibits nucleic acid replication, glycosylation of viral proteins, virus assembly, new virus particle transport and virus release. ${ }^{67}$

Chloroquine $(\mathrm{CQ})$ analogue as a late-stage autophagy disruptor

In eukaryotic cells, macroautophagy (hereafter called autophagy) is a genetically regulated evolutionary conserved catabolic process that facilitates nutrient recycling via lysosomal degradation of long-living unwanted cellular proteins as well as defective organelles, including endoplasmic reticulum. ${ }^{68,69}$ Autophagy initiates with the formation of an isolation membrane (IM) through a series of chain reactions. By sequestrating with a recognized portion of intracellular components such as damaged organelles, this IM turns into a doublemembrane vesicle called autophagosome which subsequently docks and fuses with a lysosome to become an autolysosome (AL). The contents of AL are degraded by the low $\mathrm{pH}$ and acidic enzymes such as proteases, lipases, nucleases, and glycases. ${ }^{70,71}$ This multi-step complex process involves the engulfment of targets by autophagosomes and their subsequent degradation by lysosomes. ${ }^{72}$ Lysosomal degradation is the last step in the process of autophagy, which generates molecules to be used for the synthesis of macromolecules (Figure 1a). Lysosomes, the garbage disposal system are intracellular organelles that harbored a plethora of soluble hydrolytic hydrolases capable of degrading macromolecules such as proteins, lipids, nucleic acids, polysaccharides, and cellular debris. ${ }^{73,74}$ The healthy lysosome is segregated by a single lipid bilayer from the cytoplasm and housed in highly acidic lumen environment ( $\mathrm{pH}$ of $4.5-5.0)$ relative to the slightly alkaline cytosol $(\mathrm{pH} 7.2)^{74}$ in where these catabolic events occur. The acidic $\mathrm{pH}$ of lysosomes is critical for providing an optimal condition for its most hydrolytic enzymes to perform their catalytic activities, the movement and maturation of lysosomes as well as for vesicle fusion with other vacuolar compartments such as autophagosomes, a key step in autophagy. As a late-stage autophagy inhibitor (Figure 1a), CQ has been extensively used in cancer and viral research. Furthermore, CQ can inhibit autophagy by impairing autophagosometo-lysosome fusion(Figure 1a) ${ }^{75}$ It is interesting to note that viral infection, especially Epstein-Barr virus (EBV), can activate constitutive autophagy to support virus latency. ${ }^{76} \mathrm{EBV}$-induced autophagy is dependent on the expression of viral latent membrane proteins which provide cells with an improved survival ability. In these cells, viruses inhibit lysosomal degradation in the maturation step of autophagy and use autophagic membranes for the formation and release of the viral particles. ${ }^{77}$ As a final stage autophagy inhibitor, CQ analogue is very important to protect the expression of viral latent membrane proteins as well as its survival ability in cells. As a negative regulator, mitogen-activated protein kinase (MAPK) regulates autophagy by two critical signalling pathways- mechanistic target of rapamycin (mTOR), a master regulator of autophagy -dependent and mTOR-independent pathways. ${ }^{78}$ Thus, activation of cells via MAPK signalling pathway is frequently required by viruses to achieve their replication cycle. ${ }^{79} \mathrm{CQ}$ is known to inhibit phosphorylation (activation) of the p38 MAPK in THP-1 cells as well as caspase- $1 .{ }^{80}$ In the model of HCoV-229 coronavirus, CQ reduces cellular p38 MAPK activation and inhibits viral replication. ${ }^{69}$ Thus, CQ may alter the 
2019-nCoV molecular crosstalk with its target cell by inhibiting MAPK pathway.

Chloroquine (CQ) analogue as an inhibitor of lysosomal acidification

CQ is a diprotic weak base. The structure of CQ contains a heterocyclic moiety (7chloro-quinoline) bearing a basic side chain at position 4 (Figure 1b). Two protonatable sites on the side chain are responsible for its slightly basic nature with pK's of 8.3 and 10.2, respectively, which makes it soluble in the stomach and thus orally administrable. ${ }^{39,81}$ Structurally, HCQ differs from CQ by introducing a hydroxyl group at the end of the side chain. As a result of this structural modification, HCQ has ability to decrease to cross the bloodretinal barrier for retinal toxicity. ${ }^{82-84}$ and more favourable safety profile than CQ. ${ }^{85}$ The unprotonated form of CQ diffuses spontaneously and rapidly across the membranes of cells and organelles to acidic cytoplasmic vesicles such as endosomes, lysosomes or Golgi vesicles and thereby increases their $\mathrm{pH} .{ }^{39,86}$ Mechanistically, when CQ enters the acidic vesicles like lysosome, it becomes protonated and trapped due to the high internal acidity. In cellular levels, as a lysosomal lumen alkalinizer, the trapped CQ leads to decrease the activity of lysosomal and inactivate several lysosomal enzymes, ${ }^{25,39,87}$ e.g., those required for proteolytic processing and post-translational modification of viral proteins (Figure 2a). Once oral administration, the analogue is readily absorbed and concentrated in tissues such as the lungs, liver, spleen and kidney-where several fatal viruses harboured, replicated and infected. ${ }^{88}$ By increased acidic $\mathrm{pH}$ and/or structural changes in the Golgi apparatus with HCQ or by specific interaction with CQ, various enzymes e.g. glycosylating enzymes, glycosyltransferases are inactivated and glycosylation of SARS- coronaviruses is shown to suppress. ${ }^{89,90}$ This event causes the structural changes in the gp120 glycoprotein and in turn reduces the reactivity and infectivity of newly produced virions. ${ }^{91,92}$ A group of Chinese researchers reported that CQ was highly effective in reducing viral replication in Vero E6 cells infected by $2019-\mathrm{nCoV}$ in vitrowith an $\mathrm{EC}_{90}$ (effective concentration) $6.90 \mu \mathrm{M}$ that can be easily achievable with standard dosing, due to its favourable penetration in tissues, including in the lung. ${ }^{27}$ Here CQ blocks virus infection by increasing endosomal $\mathrm{pH}$ and by interfering with the glycosylation of cellular receptor of SARS CoV. CQ also interferes with 2019-nCoV attempts to acidify the lysosomes and presumably inhibits cathepsins, which require a low $\mathrm{pH}$ for optimal cleavage of $2019-\mathrm{nCoV}$ spike protein. ${ }^{93}$

Chloroquine (CQ) analogue as an immunomodulator and anti-inflammatory agent

Lysosomes play roles in not only degradation of intracellular components, but also killing microbes in macrophages and dendritic cells through antigen processing and presentation. ${ }^{48}$ Lysosomes remove the dead cell debris by resolution of inflammation and tissue remodelling. ${ }^{94}$ The highly acidic lysosomal $\mathrm{pH}(<5)$ of scavenging M2-type macrophages are particularly effective in removing debris from tissues to help resolve inflammation; while M1 macrophages having lower lysosomal acidity $(\mathrm{pH}>5$ ) show stimulation of immune responses. An M2-to-M1 macrophage transition can be experimentally achieved by CQ at least partially through raising lysosomal $\mathrm{pH}^{95}$ Moreover, CQ has the potential to alleviate pathological conditions associated with increased M2 activity such as vascular disorder during lung carcinogenesis. ${ }^{96}$ Dendritic cells also restrict lysosomal acidification to optimize antigen processing and allow major histocompatibility complex (MHC) class-I dependent cross-presentation. ${ }^{97}$

By raising lysosomal $\mathrm{pH}$ and inhibiting lysosomal activity, CQ analogue particularly, HCQ can suppress antigen presenting cells (APCs), including plasmacytoid dendritic cells (pDCs) and B cells, and prevent antigen processing and MHC class II-mediated autoantigen presentation to T cells. ${ }^{98}$ This event mediated by $\mathrm{CQ}$ analogue also suppresses $\mathrm{T}$ cell activation, differentiation and expression of co-stimulatory proteins such as CD154 on CD4+ T cells, ${ }^{99}$ and cytokines formation T cells and B cells including interleukin 1 (IL-1), interleukin 6 (IL-6) and tumour necrosis factor-alpha $(\mathrm{TNF} \alpha) .{ }^{100}$ Beside affecting the virus maturation process, $\mathrm{pH}$ modulation by CQ can impair the proper maturation of viral protein, ${ }^{101}$ and the recognition of viral antigen by dendritic cells, which occurs through a Toll-like receptor (TLR)-dependent pathway that requires endosomal acidification. ${ }^{102} \mathrm{CQ}$ analogue administration suppresses TLR signalling pathway by altering $\mathrm{pH}$ of endosomes and interrupting binding between TLR7 and TLR9 and their RNA/DNA ligands. ${ }^{103-106}$ In the cytoplasm, the analogue also hinders the interaction between cytosolic DNA and the nucleic acid sensor c yclic G MP-A MP s ynthase (cGAS). ${ }^{107}$ Since both TLR signalling and cGAS stimulation of interferon (IFN) 
genes (the STING pathway) are hindered by CQ analogue, consequent proinflammatory signalling activation and production of cytokines such as IFNs, IL-1 and TNF, are weakened (Figure 2b). ${ }^{100}$ CQ also blocks TLR mediated activation of pDC and suppresses myeloid differentiation primary response gene 88 (MyD88) signalling by down-regulating the downstream signalling molecules, interleukin- 1 receptor associated kinase 4 (IRAK-4) and IFN regulatory factor 7 (IRF-7). ${ }^{108}$ Since TLR stimulation and production of IFN- $\alpha$ by pDC contribute to immune activation, blocking the pathway by using CQ analogues interfere emerging viral pathogenesis. ${ }^{108}$ On the other hand, CQ can provide some conflicting effects on the immune system include increasing the export of soluble antigens into the cytosol of dendritic cells and the enhancement of human cytotoxic CD8+ T cell responses against viral antigens. ${ }^{109}$

Several studies have suggested that multiple organ failure and hypovolemic shock observed in fatal cases are most likely associated with the direct viral infection as well as the effects of proinflammatory cytokines, chemokines and other mediators released from infected and activated cells such as macrophages. ${ }^{87,110-112}$ As an immunomodulatory agent, CQ analogue has also been beneficial in the treatment of viral infections and associated pathologies. ${ }^{43,44} \mathrm{CQ}$ analogue inhibits the production of several cytokines, chemokines or mediators, whose excessive appearance contributes the severity of viral infections. For example, one of the cytokines such as TNF- $\alpha$ is strongly implicated in filoviral pathologies which is able to activate macrophages. This cytokine causes to increase both the permeability and infectivity of endothelial cells. ${ }^{110,113}$ It is suggested that CQ analogues are able to prevent the activation of macrophages and inhibit the secretion of TNF- $\alpha$ from various cells at clinically relevant concentration that can confer some benefits in the treatment of viral infections. ${ }^{43,44}$ Another cytokine, IFN- $\gamma$ has also been implicated in the pathologies of viral infections (e.g., Ebola). It has been reported that IFN- $\gamma$ increase cellular sensitivity to apoptosis by up-regulating the expression of Fas and Fas ligand, ${ }^{114}$ in fatal case of Ebola infection. ${ }^{110}$ By inhibiting IFN- $\gamma$ and TNF- $\alpha$ production and preventing the activation of macrophage, ${ }^{110} \mathrm{CQ}$ analogues appear a great therapy in the treatment of patients infected with Ebola. CQ is also found to inhibit IFN $\alpha$, IFN $\beta$, IFN $\gamma$, TNF $\alpha$ and IL-6 gene expression in U937 cells infected with dengue-2 virus in vitro. ${ }^{47}$ As an adjuvant therapy, CQ analogues also regulate immune activation during HIV infection with other antiretroviral agents. The analogues are beneficial for chronic HIV-infected individuals because of reduction of systemic T-cell activation, ${ }^{115-117}$ and immune hyperactivation in HIV/AIDS. ${ }^{118}$

It has been reported that the immune response of patients infected with $2019-\mathrm{nCoV}$ virus results in the increase of cytokines IL-6 and IL-10. ${ }^{15,119}$ This may progress to a cytokine storm, followed by multi-organ failure and potentially death. Here, CQ analogue can act indirectly through reduction of proinflammatory cytokine production in COVID-19 patients. In these settings, CQ analogue may be an ideal drug to treat $2019-\mathrm{nCoV}$ infection as it can inhibit the viral mediated the cytokine storm. It is important to note that early treatment with these analogues may help to prevent the progression of the disease to a critical, lifethreatening state. Hence, it is recommended that the concomitant use of low dose HCQ with an antiinflammatory drug to help mitigate the cytokine storm in critically ill $2019-\mathrm{nCoV}$ patients. However, the uses of corticosteroids or other immunosuppressants (e.g. tocilizumab) may be detrimental in critically ill 2019-nCoV infected patients because of prominent suppression of the immune system leading to an increased risk of superinfection. ${ }^{120,121}$

Chloroquine (CQ) analogue as a restrictor for binding of coronaviral receptors to target cells

Like other human coronaviruses, SARS CoV2 harbours three envelope proteins, the spike (S) protein (180$220 \mathrm{kDa})$, the membrane $(\mathrm{M})$ protein $(25-35 \mathrm{kDa})$ and the envelope $(\mathrm{E})$ protein $(10-12 \mathrm{kDa})$, which are required for entry of infectious virions into target cells. Using non-human coronavirus, it is shown that the M protein which localises to the trans-Golgi network, plays a vital role during viral assembly by interacting with the other proteins of the virus. Following assembly, the newly formed viral particles are transported to the cell surface in vesicles and are released by exocytosis. ${ }^{41,122} \mathrm{CQ}$ interferes with proteolytic processing of the $\mathrm{M}$ protein maturation, ${ }^{25}$ and may alter virion assembly and budding of $2019-\mathrm{nCoV}$ at the replication cycle.

It has also been reported that SARS-CoV-1 and MERS-CoV upregulate the angiotensin-converting enzyme 
2 (ACE2) expression in lungs, a process that can accelerate their replication and spread. ${ }^{123} 2019-\mathrm{nCoV}$ is also found to utilise the same cell surface receptor ACE2 (expressed in lung, heart, kidney and intestine). ${ }^{123,124}$ Binding to ACE2, 2019-nCoV can trigger conformational changes in the $\mathrm{S}$ glycoprotein allowing cleavage by the transmembrane protease TMPR-SS2 of the S protein and the release of S fragments into the cellular supernatant. ${ }^{124,125,126}$ In vitro SARS-CoV-1 model, CQ has been shown to exert an attributable antiviral effect during pre- and post-infection conditions by interfering with the glycosylation of a viral cell surface receptor, ACE2 and blocking virus fusion with the host Vero cells. ${ }^{90}$ This impaired terminal glycosylation of ACE2 may diminish the binding efficacy between ACE2 on target cells and the S protein of 2019-nCoV and consequently prevent infection.

A pH-dependant entry of coronavirus, SARS-CoV-1 into target cells is also mediated by $\mathrm{S}$ protein after binding of the DC-SIGN receptor. ${ }^{127}$ The activation step that occurs in acidic endosomes results in fusion of the viral and endosomal membranes leading to the release of the viral SARS-CoV-1 genome into the cytosol. ${ }^{128}$ In the absence of antiviral drug, the virus is targeted to the lysosome where lysosomal enzymes disrupt the viral particle and liberate the infectious nucleic acid for its replication. ${ }^{129} \mathrm{CQ}$ analogue can inhibit a pre-entry step of the viral cycle by interfering with viral particles binding to their cell surface receptor. The acidic monosaccharides, sialic acids found in cell transmembrane proteins are critical components of ligand recognition. CQ inhibits quinone reductase $2,{ }^{130}$ a structural neighbour of UDP-N-acetylglucosamine 2 -epimerases, ${ }^{131}$ that are involved in the biosynthesis of sialic acids. The possible interference of CQ with sialic acid biosynthesis can account for the broad antiviral spectrum against $\mathrm{HCoV}-\mathrm{O} 43$ because of sialic acid moieties as its receptors. ${ }^{132}$ Although the binding of SARS-CoV to sialic acids has not been reported so far, if 2019-nCoV like other coronaviruses targets sialic acids on some cell subtypes, this interaction may also be affected by CQ treatment. ${ }^{133,134}$

\section{Clinical trials of chloroquine (CQ) analogues against COVID-19}

A recent study suggests that CQ is found to block COVID-19 infection at low-micromolar concentration, with a half-maximal effective concentration $\left(\mathrm{EC}_{50}\right)$ of $1.13 \mu \mathrm{M}$ and a half-cytotoxic concentration $\left(\mathrm{CC}_{50}\right)$ greater than $100 \mu \mathrm{M}$ after a 48-hour incubation time in vitro. ${ }^{27}$ Recently, In vitro five FDA-approved drugs and two broad spectrum antivirals have been evaluated against a clinical isolate of $2019-\mathrm{nCoV} .{ }^{27}$ The above report concludes that "CQ is highly effective in the control of 2019-nCoV infection in vitro " and its "safety track record suggests that it should be assessed in human patients suffering from the novel coronavirus disease". Thus, several clinical trials are currently investigating the use of CQ analogues particularly HCQ to treat 2019-nCoV infection. In addition, recently an open label non-RCT study of twenty COVID-19 cases indicates that the combination of HCQ (600mg daily) and azithromycin is significantly associated with viral load reduction/disappearance in COVID-19 patients compared to controls. The addition of azithromycin to the HCQ combination causes significantly more efficient for virus elimination. ${ }^{135}$ However, it is important to note that the dosing regimens used in these trials are mainly based on previous clinical experience, raising the alarm that adverse effects may occur in study participants. In these studies, an optimized dosing regimen is designed as high loading dose and low maintenance dose HCQ based on its unique pharmacokinetics (i.e. high accumulation in cells and long elimination half-life).

Another recent publication also suggests that CQ phosphate is superior to the control treatment in inhibiting the exacerbation of pneumonia, improving lung imaging findings, promoting a virus negative conversion, and shortening the disease course. ${ }^{29}$ Severe adverse reactions to CQ phosphate are not noted in the aforementioned patients. ${ }^{29}$ These clinical trials are conducted in different hospitals and possibly followed a number of different clinical protocols among those listed in Table 3. These trials also include various designs for control groups (none, different antivirals, placebo, etc.) and various outcome primary indicators. The final interpretation is therefore technically demanding, and in the absence of published data, it is difficult to reach any firm conclusion. It is also the utmost importance to know if the observed efficacy is associated specifically with CQ phosphate, or if this includes other salts (e.g., sulfate) of CQ, and HCQ. It is also necessary to determine if the benefit of CQ therapy depends on the Age and sex class, the clinical presentation or the stage of the disease. 


\section{Other potential repurposing candidates for the treatment of COVID-19}

Immediate therapeutic options in response to the 2019-nCoV outburst are urgently needed. So, a number of repurposing available candidates have joined the list of antiviral agents that can be used as therapeutic arsenal against COVID-19.

Virally targeted agents

FDA approved nucleoside analogues such as favipiravir (T-705) and ribavirin and experimental nucleoside analogues including remdesivir (GS-5734) may have potential against 2019-nCoV. Favipiravir approved for influenza treatment can effectively inhibit the RNA-dependent RNA polymerase of RNA viruses such as influenza, Ebola and chikungunya. ${ }^{136}$ A recent study suggests its activity against 2019-nCoV at $\mathrm{EC}_{50}=$ $61.88 \mu \mathrm{M}$ in Vero E6 cells. ${ }^{27}$ Thus, patients with $2019-\mathrm{nCoV}$ are being recruited in randomized clinical trials (RCT) to evaluate the efficacy of favipiravir plus interferon- $\alpha$ (ChiCTR2000029600) and favipiravir plus baloxavir marboxil, an approved influenza inhibitor (ChiCTR2000029544). ${ }^{23}$ Ribavirin approved for treating hepatitis $\mathrm{C}$ virus (HCV) and respiratory syncytial virus (RSV), has been evaluated in patients with SARS and MERS, but its side effects including anaemia may be prominent at high doses, ${ }^{137}$ and its sufficient potency against $2019-\mathrm{nCoV}$ is uncertain. Remdesivir has broad-spectrum activities against RNA viruses such as MERS and SARS in cell cultures and animal models, and has also been tested in a clinical trial for Ebola. ${ }^{23} \mathrm{~A}$ recent study indicates that remdesivir inhibits $2019-\mathrm{nCoV}$ at $\mathrm{EC}_{50}=0.77$ $\mu \mathrm{M}$ in Vero E6 cells. ${ }^{27}$ Two phase III trials (NCT04252664 and NCT04257656) have already been initiated in early February to evaluate remdesivir in patients with 2019-nCoV. Other FDA-approved drugs such as penciclovir, nafamostat, lopinavir and ritonavir have also been evaluated for the antiviral efficiency. Protease inhibitors such as lopinavir and ritonavir have been reported to be active against SARS and MERS and their clinical trials (e.g., ChiCTR2000029539) have been initiated to test the efficacies in patients infected with 2019-nCoV.

Host-targeted agents

Teicoplanin, a glycopeptide antibiotic routinely used to treatStaphylococcal infections, has showed efficacy against various viruses such as Ebola, influenza, HIV, and on coronaviruses such as MERS-CoV and SARSCoV. ${ }^{138,139}$ In coronaviruses, teicoplanin acts on the early step of the viral life cycle in human cells by inhibiting the low $\mathrm{pH}$ cleavage of the viral $\mathrm{S}$ protein by cathepsin $\mathrm{L}$ in the late endosomes thereby preventing viral replication cycle. ${ }^{138}$ This activity is conserved on SARS CoV-2 as the target spike S protein sequence that serve as cleavage site for cathepsin $\mathrm{L},{ }^{140}$ and the concentration of teicoplanin required to inhibit $50 \%$ of viruses $\left(\mathrm{IC}_{50}\right)$ is $1.66 \mu \mathrm{M}$ in vitro.$^{141}$ Pegylated interferon $\alpha-2 \mathrm{a}$ and $-2 \mathrm{~b}$, approved for the treatment of hepatitis $\mathrm{B}$ virus (HBV) and $\mathrm{HCV}$, can be used to stimulate innate antiviral responses in patients infected with 2019-nCoV, and trials involving interferons have been initiated, such as a combination of pegylated interferon plus ribavirin (ChiCTR2000029387). However, it is uncertain whether this combination could act synergistically against 2019-nCoV. ${ }^{23}$ Nitazoxanide, approved for diarrhoea treatment, can also inhibit 2019 $\mathrm{nCoV}_{\text {at }} \mathrm{EC}_{50}=2.12 \mu \mathrm{M}$ in Vero E6 cells. ${ }^{27}$ The antiviral efficacy of such agents needs to be assessed in clinical studies.

\section{Conclusions, recommendations and future perspective}

CQ analogue particularly HCQ is considered to be safe and a cheap drug, and its side-effects are generally mild and transitory. As a result, it has been used for more than 100 years. CQ approved by FDA for malaria treatment, has long been prescribed prophylactically to pregnant women at risk of exposure to Plasmodium parasites. ${ }^{142}$ As an anti-inflammatory agent, these analogues are efficacious for the treatment of rheumatoid arthritis and systemic lupus erythematosus. ${ }^{39} \mathrm{HCQ}$ is found to be more potent than CQ at inhibiting 2019$\mathrm{nCoV}$ in vitro. Thus, $\mathrm{CQ}$ analogue reportedly exhibits antiviral activities with in vitro efficacy against several viruses, including coronaviruses; ${ }^{143}$ however, real time data concerning its in vivo efficacy during viral infection and anti-CoV activity in living animals remains limited. In light of the possibility of using CQ to fight orphan viral infections, ${ }^{67}$ and the urgent clinical demand, CQ analogue shows potentially favourable risk-benefit balance, that is the relatively high safety, and the low expenditure of such treatment in the context 
of the current COVID-19 outbreak. ${ }^{144}$ There is sufficient pre-clinical rationale and evidence regarding the effectiveness of CQ analogue for treatment of COVID-19 as well as evidence of safety from long-time use in clinical practice for other indications. ${ }^{41}$ Since the current COVID-19 outbreak cases were reported in more than 85 countries so far, the low cost of CQ is a major benefit for both the highly stressed healthcare systems of involved high-income countries and the underfunded heath care systems of middle- and low-income counties. ${ }^{145}$ Thus, CQ analogue may become a real breakthrough as broad-spectrum anti-coronaviral agents to treat COVID-19 for future epidemics.

The margin of safety between the therapeutic and toxic dose is narrow and CQ poisoning has been associated with cardiovascular disorders and retinopathy that can be life-threatening. ${ }^{146}$ Therefore, these analogue uses should be subjected to strict rules, and self-treatment is not recommended. The vital ethical issue is administration of CQ analogue in the setting of COVID-19 is experimental as declared by WHO, and therefore it requires ethical trial approval, or off-label (i.e. ethically justifiable as the best available treatment). As even off-label use of CQ, it may be accompanied by several concerns; the first priority is patient safety. Such use should be accompanied by close monitoring. In case of epidemic situation, it is hardly the ideal setting to do this. Moreover, the ethical approach to off-label drug use also differs between countries. ${ }^{24}$ Thus, based onin vitro evidence and still unpublished clinical experience, the expert panel recommended CQ phosphate tablet, at a dose of $500 \mathrm{mg}$ twice per day for 10 days, for patients diagnosed as mild, moderate and severe cases of $2019-\mathrm{nCoV}$ pneumonia, provided that there were no contraindications to the drug. ${ }^{18,147}$ The panel recommends using several precautions, including blood testing to rule out the development of anaemia, thrombocytopenia or leukopenia as well as serum electrolyte disturbances and/or hepatic and renal function dysfunction. Other recommendations are routine electrocardiography to rule out the development of QT interval prolongation or bradycardia and patient interviews to seek the appearance of visual and/or mental disturbance/deterioration. The Dutch Centre of Disease control (CDC) suggested to treat severe infections requiring admission to the hospital and oxygen therapy or admitted to the ICU with CQ. ${ }^{24,148}$

Although the use of $\mathrm{CQ}$ analogue may be supported by expert opinion, clinical use of this drug in patients with COVID-19 should adhere to the Monitored Emergency Use of Unregistered Interventions Framework (MEURI) framework or after ethical approval as a trial as stated by the WHO. Data from high-quality, coordinated, clinical trials coming from different locations worldwide are urgently needed. The worldwide ongoing clinical trials will verify whether the hopes raised by CQ in the treatment of COVID-19 can be confirmed. The rapid identification of effective interventions against $2019-\mathrm{nCoV}$ is a major challenge. Given the available knowledge on their safety profiles, and in some cases efficacy against closely related coronaviruses, repurposing existing antiviral agents is a potentially important near-term strategy to tackle 2019-nCoV. With the ongoing efforts to prevent the spread of 2019-nCoV worldwide, we hope that the outbreak may subside in a few months, as with SARS and MERS. Nevertheless, the outbreak has emphasized the urgent need for renewed efforts to develop broad-spectrum antiviral agents to combat coronaviruses.

\section{Acknowledgements}

The author would like to acknowledge Professor M. Shahabuddin K Choudhuri, Department of Pharmacy, Jahangirnagar University and Bangladesh Biosafety and Biosecurity Society (BBBS) for technical assistance with the literature search.

Competing Interests: The authors declare that they have no competing interests.

Ethical approval: Not required.

Transparency declarations: None to declare.

\section{References}

1. Adams MJ, Lefkowitz EJ, King AM, et al. Ratification vote on taxonomic proposals to the international committee on taxonomy of viruses (2016). Arch Virol 2016; 161 : 2921-2949. doi:10.1007/s00705016-2977-6. 
2. Perlman S, Netland J. Coronaviruses post-SARS: update on replication and pathogenesis. Nat Rev Microbiol 2009; 7 : 439-450. doi:10.1038/nrmicro2147.

3. Larson HE, Reed SE, Tyrrell DA. Isolation of rhinoviruses and coronaviruses from 38 colds in adults. J Med Virol 1980;5 : 221-229.

4. Niua J, Shenb L, Huanga B, et al. Non-invasive bioluminescence imaging of HCoV-OC43 infection and therapy in the central nervous system of live mice.Antiviral Research 2020; 173: 104646. doi:10.1016/j.antiviral.2019.10

5. Arden KE, Nissen MD, Sloots TP, et al. New human coronavirus, HCoV-NL63, associated with severe lower respiratory tract disease in Australia. J Med Virol 2005; 75 : 455-462. doi:10.1002/jmv.20288.

6. van der Hoek L, Pyrc K, Jebbink MF, et al. Identification of a new human coronavirus. Nat Med 2004; 10 : 368-373. doi:10.1038/nm1024.

7. Woo PC, Lau SK, Tsoi HW, et al. Clinical and molecular epidemiological features of coronavirus HKU1-associated community-acquired pneumonia. J Infect Dis 2005; 192 : 1898-1907. doi:10.1086/497151.

8. Ksiazek TG, Erdman D, Goldsmith CS, et al. A novel coronavirus associated with severe acute respiratory syndrome. N Engl J Med2003; 348 : 1953-1966. doi:10.1056/NEJMoa030781.

9. Gralinski LE, Baric RS, Molecular pathology of emerging coronavirus infections. J Pathol 2015; 235 : 185-195. doi:10.1002/path.4454.

10. Milne-Price S, Miazgowicz KL, Munster VJ. The emergence of the Middle East respiratory syndrome coronavirus. Pathog Dis 2014;71 : 121-136. doi:10. 1111/2049-632X.12166.

11. Arabi YM, Harthi A, Hussein J, et al. Severe neurologic syndrome associated with Middle East respiratory syndrome corona virus (MERS-CoV). Infection 2015; 43 : 495-501. doi:10.1007/s15010015-0720-y.

12. Arbour N, Day R, Newcombe J, et al. Neuroinvasion by human respiratory coronaviruses. J Virol 2000; 74 : 8913-8921. doi:10.1128/jvi.74.19. 8913-8921.2000.

13. Morfopoulou S, Brown JR, Davies EG, et al. Human coronavirus OC43 associated with fatal encephalitis. N. Engl J Med 2016;375 : 497-498. doi:10.1056/NEJMc1509458.

14. Koyuncu OO, Hogue IB, Enquist LW. Virus infections in the nervous system. Cell Host Microbe 2013; 13 : 379-393. doi:10.1016/j.chom.2013.03.010.

15. Huang C, Wang Y, Li X, et al. Clinical features of patients infected with 2019 novel coronavirus in Wuhan, China. Lancet2020; 395 : 497-506. doi:10.1016/S0140-6736(20)30183-5.

16. Zhu N, Zhang D, Wang W, et al. A novel coronavirus from patients with pneumonia in China, 2019. $N$ Engl J Med 2020;382:727-33.

17. Zhou P, Yang XL, Wang XG, et al. Discovery of a novel coronavirus associated with the recent pneumonia outbreak in humans and its potential bat origin. bioRxiv 2020. doi:10.1101/2020.01.22.914952.

18. Lai C-C, Liu YH, Wang C-Y,et al. Asymptomatic carrier state, acute respiratory disease, and pneumonia due to severe acute respiratory syndrome coronavirus 2 (SARS-CoV-2): Facts and myths. $J$ Microbiol, Immunol Infection2020; doi:10.1016/j.jmii.2020.02.012

19. Huang WH, Teng LC, Yeh TK, et al . 2019 novel coronavirus disease (COVID-19) in Taiwan: reports of two cases from Wuhan, China.J Microbiol Immunol Infect 2020; doi:10.1016/j.jmii.2020.02.009.

20. Liu YC, Liao CH, Chang CF, et al . A locally transmitted case of SARS-CoV-2 infection in Taiwan. N Engl J Med 2020; doi:10.1056/NEJMc2001573.

21. Lee PI, Hsueh PR. Emerging threats from zoonotic coronaviruses-from SARS and MERS to 2019-nCoV. J Microbiol Immunol Infect 2020;20 :30011e6. doi:10.1016/j.jmii.2020.02.001.

22. WHO Director-General's opening remarks at the media briefing on COVID-19 - 11 March 2020. [https://www.who.int/dg/speeches/detail/who-director-general-s-opening-remarks-at the-media-briefingon-covid-19-11-march-2020]

23. Li G, De Clercq E. Therapeutic options for the 2019 novel coronavirus (2019-nCoV). Nat Rev Drug Discov 2020; 19 :149-150. doi:10.1038/ d41573-020-00016-0

24. Cortegiani A, Ingoglia G, Ippolito M, et al. A systematic review on the efficacy and safety of chloroquine for the treatment of COVID-19. J Critical Care 2020; doi:10.1016/j.jcrc.2020.03.005

25. Savarino A, Boelaert JR, Cassone A, et al. Effects of chloroquine on viral infections: an old drug against today's diseases. Lancet Infect Dis 2003;3 : 722-727. doi:10.1016/S1473-3099(03)00806-5. 
26. Colson P, Rolain J-M, Raoult D. Chloroquine for the 2019 novel coronavirus SARS CoV-2. Int J Antimicrob Agents 2020;105923. doi:10.1016/j.ijantimicag.2020.105923.

27. Wang M, Cao R, Zhang L, et al. Remdesivir and chloroquine effectively inhibit the recently emerged novel coronavirus (2019 nCoV) in vitro . Cell Res 2020; 30 : 269-271. doi:10.1038/s41422-020-0282-0.

28. Lu H. Drug treatment options for the 2019-new coronavirus (2019-nCoV).Biosci Trends 2020;

29. Gao J, Tian Z, Yang X. Breakthrough: Chloroquine phosphate has shown apparent efficacy in treatment of COVID-19 associated pneumonia in clinical studies BioSci Trends 2020; 14: 72-73. doi: $10.5582 /$ bst.2020.01047

30. Colson P, Rolain JM, Lagier JC, et al. Chloroquine and hydroxychloroquine as available weapons to fight COVID-19. Int $J$ Antimicrob Agents 2020; 105932. doi: 10.1016/j.ijantimicag.2020.105932.

31. Multicenter Collaboration Group of Department of Science and Technology of Guangdong Province and Health Commission of Guangdong Province for Chloroquine in the Treatment of Novel Coronavirus Pneumonia Expert consensus on chloroquine phosphate for the treatment of novel coronavirus pneumonia [in Chinese]. Zhonghua Jie He He Hu Xi Za Zhi 2020;43 : E019. doi:10.3760/cma.j.issn.10 01-0939.2020.0 019.

32. DiMasi JA, Grabowski HG, Hansen RW. Innovation in the pharmaceutical industry: New estimates of R \& D costs. J Health Econ 2016;47:20-33.

33. The Pharmaceutical Journal. Return on investment falls for pharmaceutical industry. 2017; doi: 10.1211/PJ.2017.20202146

34. Aitken M, Kleinrock M. Global medicines use in 2020: outlook and implications. IMS Institute for healthcare informatics.2015;1-4

35. Hernandez JJ, Pryszlak M, Smith L, et al. Giving drugs a second chance: Overcoming regulatory and financial hurdles in repurposing approved drugs as cancer therapeutics. Front Oncol. 2017;7 :273.

36. Abbruzzese C, Matteoni S, Signore M, et al. Drug repurposing for the treatment of glioblastoma multiforme. J Exp Clin Cancer Res 2017; 36 :169.

37. Ashburn TT, Thor KB. Drug repositioning: Identifying and developing new uses for existing drugs. Nat Rev Drug Discov 2004;3:673-683.

38. Vazquez-Martin A, Lopez-Bonetc E, Cufi S, et al . Repositioning chloroquine and metformin to eliminate cancer stem cell traits in pre-malignant lesions. Drug Resist Update 2011;14 :212-223.

39. Al-Bari MAA. Chloroquine analogues in drug discovery: new directions of uses, mechanisms of actions and toxic manifestations from malaria to multifarious diseases. J Antimicrob Chemother 2015;70 $: 1608-1621$.

40. Barrow E, Nicola AV, Liu J. Multiscale perspectives of virus entry via endocytosis. Virol J 2013; 10 $: 177$.

41. Devaux CA, Rolain J-M, Colson P, Raoult D. New insights on the antiviral effects of chloroquine against coronavirus: what to expect for COVID-19? Intl J Antimicrobial Agents 2020; doi:10.1016/j.ijantimicag.2020.105938.

42. Keyaerts $\mathrm{E}$, Vijgen L, Maes $\mathrm{P}$, et al. In vitro inhibition of severe acute respiratory syndrome coronavirus by chloroquine.Biochem Biophys Res Commun 2004; 323 :264-268. doi:10.1016/j.bbrc.2004.08.085.

43. Al-Bari MAA. Targeting endosomal acidification by chloroquine analogs as a promising strategy for the treatment of emerging viral diseases.Pharmacol Res Perspect 2017; 5 : e00293

44. Akpovwa H. Chloroquine could be used for the treatment of filoviral infections and other viral infections that emerge or emerged from viruses requiring an acidic $\mathrm{pH}$ for infectivity. Cell Biochem Funct 2016; 34 :191-196. doi: 10.1002/cbf.3182

45. Yan Y, Zou Z, Sun Y, et al . Anti-malaria drug chloroquine is highly effective in treating avian influenza A H5N1 virus infection in an animal model. Cell Res 2013; 23 :300-302. doi: 10.1038/cr.2012.165.

46. Delogu I, de Lamballerie X. Chikungunya disease and chloroquine treatment. J Med Virol2011; 83 :1058-1059. doi:10.1002/jmv.22019.

47. Farias KJ, Machado PR, de Almeida Junior RF, et al. Chloroquine interferes with dengue-2 virus replication in U937 cells. Microbiol Immunol 2014; $58: 318-26$.

48. Ferraris O, Moroso M, Pernet O, et al . Evaluation of Crimean-Congo hemorrhagic fever virusin vitro inhibition by chloroquine and chlorpromazine, two FDA approved molecules. Antiviral Res 2015; 118 
:75-81. doi:10.1016/j.antiviral.2015.03.005.

49. Coombs K, Mann E, Edwards J, et al. Effects of chloroquine and cytochalasin B on the infection of cells by Sindbis virus and vesicular stomatitis virus. J Virol 1981;37:1060-1065.

50. Roques P, Thiberville S-D, Dupuis-Maguiraga L, et al.Paradoxical effect of chloroquine treatment in enhancing chikungunya virus infection. Viruses 2018; 10 . doi..org/10.3390/v10050268.

51. De Lamballerie X, Boisson V, Reynier J-C, et al. On chikungunya acute infection and chloroquine treatment. Vector Borne Zoonotic 2008; 8 :837-839. doi:10.1089/vbz.2008.0049.

52. Chauhan A, Tikoo A. The enigma of the clandestine association between chloroquine and HIV-1 infection. HIV Med 2015;16 :585-590. doi:10.1111/hiv.12295.

53. Helal GK, Gad MA, Abd-Ellah, MF, et al . Hydroxychloroquine augments early virological response to pegylated interferon plus ribavirin in genotype-4 chronic hepatitis C patients. J Med Virol 2016; $88: 2170-2178$. doi:10.1002/jmv.24575.

54. Peymani P, Yeganeh B, Sabour S, et al. New use of an old drug: chloroquine reduces viral and ALT levels in HCV non-responders (a randomized, triple-blind, placebo-controlled pilot trial). Can J Physiol Pharmacol 2016; 94 :613-619. doi:10.1139/cjpp-2015-0507.

55. Keyaerts E, Li S, Vijgen L, et al. Antiviral activity of chloroquine against human coronavirus OC43 infection in newborn mice.Antimicrob Agents Chemother 2009;53 : 3416-3421. doi:10. 1128/AAC.0150908.

56. Li C, Zhu X, Ji X, et al. Chloroquine, a FDA-approved drug, prevents Zika virus infection and its associated congenital microcephaly in mice. EBioMedicine 2017; 24 :189-194. doi:10.1016/j.ebiom.2017.09.034.

57. Vigerust DJ, McCullers JA. Chloroquine is effective against influenza A virus in vitro but not in vivo . Viruses 2007;1 : 189-192. doi:10. 1111/j.1750-2659.2007.00027.x.

58. Tricou V, Minh NN, Van TP, et al. A randomized controlled trial of chloroquine for the treatment of dengue in Vietnamese adults.PLoS Neglected Trop Dis 2010; 4 : e785. doi:10.1371/journal.pntd.0000785.

59. Kono M, Tatsumi K, Imai AM, et al. Inhibition of human coronavirus 229E infection in human epithelial lung cells (L132) by chloroquine: involvement of p38 MAPK and ERK. Antiviral Res2008; 77 :150-2. doi:10.1016/j.antiviral.2007.10.011.

60. Shen L, Yang Y, Ye F, et al. Safe and sensitive antiviral screening platform based on recombinant human coronavirus OC43 expressing the luciferase reporter gene. Antimicrob Agents Chemother 2016; 60 :5492-503. doi:10.1128/AAC.00814-16.

61. de Wilde AH, Jochmans D, Posthuma CC, et al. Screening of an FDA-approved compound library identifies four small-molecule inhibitors of Middle East respiratory syndrome coronavirus replication in cell culture.Antimicrob Agents Chemother 2014; 58 :4875-84. doi:10.1128/AAC.03011-14.

62. Mo Y, Fisher D. A review of treatment modalities for Middle East respiratory syndrome. J Antimicrob Chemother 2016;71 :3340-3350.

63. Burkard C, Verheije MH, Wicht O, et al. Coronavirus cell entry occurs through the endo/lysosomal pathway in a proteolysis-dependent manner. PLoS Pathog 2014; 10 :e1004502.

64. Lee SJ, Silverman E, Bargman JM. The role of antimalarial agents in the treatment of SLE and lupus nephritis. Nat Rev Nephrol 2011;7 :718-29. doi:10.1038/nrneph.2011.150.

65. Bernstein HN. Ocular safety of hydroxychloroquine. Ann Ophthalmol 1991; 23 :292-6.

66. Cubero GJ, Rodriguez Reguero JJ, Rojo Ortega JM. Restrictive cardiomyopathy caused by chloroquine. Br Heart $J$ 1993;69:451-2.

67. Rolain JM, Colson P, Raoult D. Recycling of chloroquine and its hydroxyl analogue to face bacterial, fungal and viral infection in the 21st century. Int J Antimicrob Agents 2007;30 :297-308.

68. Galluzzi L, Bravo-San Pedro JM, Blomgren K, et al. Autophagy in acute brain injury. Nat Rev Neurosci 2016; 17 :467-484.

69. Galluzzi L, Bravo-San Pedro JM, Levine B, et al.Pharmacological modulation of autophagy: Therapeutic potential and persisting obstacles. Nat Rev Drug Discov 2017;16 :487-511.

70. Kaur J, Debnath J. Autophagy at the crossroads of catabolism and anabolism. Nat Rev Mol Cell Biol. 2015; $16: 461-472$.

71. Mizushima N, Komatsu M. Autophagy: renovation of cells and tissues. Cell 2011;147 :728-741. 
72. Rockel JS, Kapoor M. Autophagy: controlling cell fate in rheumatic diseases. Nat Rev Rheumatol.2017;13:193.

73. Saftig P, Klumperman J. Lysosome biogenesis and lysosomal membrane proteins: trafficking meets function. Nat Rev Mol Cell Biol 2009; 10 : 623-35.

74. Ballabio A. The awesome lysosome. EMBO Mol Med. 2016;8 :73-76.

75. Mauthe M, Orhon I, Rocchi C, et al. Chloroquine inhibits autophagic flux by decreasing autophagosomelysosome fusion.Autophagy 2018; $14: 1435-1455$. doi:10.1080/15548627.2018.1474314.

76. Pujals A, Favre L, Pioche-Durieu C, et al. Constitutive autophagy contributes to resistance to TP53mediated apoptosis in Epstein-Barr virus-positive latency III B-cell lymphoproliferations. Autophagy $2015 ; 11$ :2275-2287. doi:10.1080/15548627.2015.111593.

77. Maclean KH, Dorsey FC, Cleveland JL, et al. Targeting lysosomal degradation induces p53dependent cell death and prevents cancer in mouse models of lymphomagenesis. $J$ clin invest 2008; $118: 79-88$. doi:10.1172/JCI33700.

78. Al-Bari MAA, Xu P. Molecular regulation of autophagy machinery by mTOR-dependent and -independent pathways. Ann N Y Acad Sci2020; doi: 10.1111/nyas.14305.

79. Briant L, Robert-Hebmann V, Acquaviva C, et al. The protein tyrosine kinase p56lck is required for triggering $\mathrm{NF}-\varkappa \mathrm{B}$ activation upon interaction of human immunodeficiency virus type 1 envelope glycoprotein gp120 with cell surface CD4. J Virol 1998;72:6207-6214.

80. Steiz M, Valbracht J, Quach J, et al. Gold sodium thiomalate and chloroquine inhibit cytokine production in monocytic THP-1 cells through distinct transcriptional and posttranslational mechanisms. $J$ Clin Immunol 2003; 23 :477-484. doi:10.1023/B:JOCI.0000010424.41475.17.

81. Schlesinger PH, Krogstad DJ, Herwaldt BL. Antimalarial agents: mechanisms of action. Antimicrob Agents Chemother 1988;32 :793-798. doi:10.1128/AAC.32.6.793.Updated.

82. Raines MF, Bhargava SK, Rosen ES. The blood-retinal barrier in chloroquine retinopathy.Investigative Ophthalmol Visual Sci 1989;30:1726-1731.

83. Grierson DJ. Hydroxychloroquine and visual screening in a rheumatology outpatient clinic. Annals Rheumatic Diseases 1997;56 :188-90.

84. Mavrikakis I. The incidence of irreversible retinal toxicity in patients treated with hydroxychloroquine: a reappraisal. Ophthalmol 2003; $110: 1321-6$.

85. Ruiz-Irastorza G, Ramos-Casals M, Brito-Zeron $\mathrm{P}$, et al.Clinical efficacy and side effects of antimalarials in systemic lupus erythematosus: a systematic review. Ann Rheum Dis 2010;69 : 20-28.

86. Lamoureux F, Thomas C, Crafter C, et al. Blocked autophagy using lysosomotropic agents sensitizes resistant prostate tumor cells to the novel Akt inhibitor AZD5363. Clin Cancer Res 2012; 19 : 833-44.

87. Marzi A, Reinheckel T, Feldmann H. Cathepsin B and L are not required for Ebola virus replication. PLoS Negl Trop Dis 2012;6 :e1923.

88. Geisbert TW, Hensley LE, Larsen T, et al. Pathogenesis of Ebola hemorrhagic fever in cynomolgus macaques: evidence that dendritic cells are early and sustained targets of infection. Am J Pathol 2003; $163: 2347-2370$.

89. Savarino A, Di Trani L, Donatelli I, et al. New insights into the antiviral effects of chloroquine. Lancet Infect Dis 2006;6 :67-69.

90. Vincent MJ, Bergeron E, Benjannet S, et al. Chloroquine is a potent inhibitor of SARS coronavirus infection and spread. Virol $J$ 2005; 2 :69. doi:10.1186/1743-422X-2-69.

91. Savarino A, Lucia MB, Rastrelli E, et al. Anti-HIV effects of chloroquine: inhibition of viral particle glycosylation and synergism with protease inhibitors. J Acquir Immune Defic Syndr 2004;35 :223-232.

92. Naarding MA, Baan E, Pollakis G, et al. Effect of chloroquine on reducing HIV-1 replication in vitro and the DC-SIGN mediated transfer of virus to CD4+ T-lymphocytes. Retrovirol 2007; $4: 6$.

93. Simmons G, Bertram S, Glowacka I, et al. Different host cell proteases activate the SARS-coronavirus spike protein for cell-cell and virus-cell fusion. Virology 2011; 413 :265-274. doi:10.1016/j.virol.2011.02.020.

94. Lim JJ, Grinstein S, Roth Z. Diversity and versatility of phagocytosis: roles in innate immunity, tissue remodeling, and homeostasis. Frontiers in cell infect microbiol 2017;7 :191. doi:10.3389/fcimb.2017.00191.

95. Chen D, Xie J, Fiskesund R, et al. Chloroquine modulates antitumor immune response by resetting 
tumor associated macrophages toward M1 phenotype. Nat commun 2018; 9 :873. doi:10.1038/s41467018-03225-9

96. Li GG, Guo ZZ, Ma XF, et al. The M2 macrophages induce autophagic vascular disorder and promote mouse sensitivity to urethane-related lung carcinogenesis. Dev Comp Immunol 2016;59 :89-98. doi:10.1016/j.dci.2016.01.010.

97. Alloatti A, Kotsias F, Magalhaes JG, et al. Dendritic cell maturation and cross-presentation: timing matters! Immunol reviews 2016; 272 :97-108. doi:10.1111/imr.12432

98. Lotteau V, Teyton L, Peleraux A et al. Intracellular transport of class II MHC molecules directed by invariant chain. Nature 1990; $348: 600-5$.

99. Wu SF, Chang CB, Hsu JM et al. Hydroxychloroquine inhibits CD154 expression in CD4(+) T lymphocytes of systemic lupus erythematosus through NFAT, but not STAT5, signalling. Arthritis Res Ther 2017; 19 :183.

100. vanden Borne BE, Dijkmans BA, de Rooij HH et al. Chloroquine and hydroxychloroquine equally affect tumor necrosis factor-alpha, interleukin 6 , and interferon-gamma production by peripheral blood mononuclear cells. J Rheumatol 1997; 24 :55-60.

101. Randolph VB, Winkler G, Stollar V. Acidotropic amines inhibit proteolytic processing of flavivirus prM protein. Virology1990; 174 :450-458. doi:10.1016/0042-6822(90)90099-d.

102. Diebold SS, Kaisho T, Hemmi H, et al. Innate antiviral responses by means of TLR7-mediated recognition of single stranded RNA. Science 2004; $303: 1529-31$.

103. Ewald SE, Lee BL, Lau L et al. The ectodomain of Toll-like receptor 9 is cleaved to generate a functional receptor. Nature $2008 ; 456: 658-62$.

104. Kuznik A, Bencina M, Svajger U et al. Mechanism of endosomal TLR inhibition by antimalarial drugs and imidazoquinolines. J Immunol 2011; 186 : 4794-804.

105. Hacker H, Mischak H, Miethke T et al. CpG-DNA-specific activation of antigen-presenting cells requires stress kinase activity and is preceded by non-specific endocytosis and endosomal maturation. EMBO J 1998; 17: 6230-40.

106. Vollmer J, Tluk S, Schmitz C et al. Immune stimulation mediated by autoantigen binding sites within small nuclear RNAs involves Toll-like receptors 7 and 8. J Exp Med 2005; 202 :1575-85.

107. An J, Woodward JJ, Sasaki T et al. Cutting edge: antimalarial drugs inhibit IFN-b production through blockade of cyclic GMP-AMP synthase-DNA interaction. J Immunol 2015;194:4089-93.

108. Martinson JA, Montoya CJ, Usuga X, et al . Chloroquine modulates HIV-1-induced plasmacytoid dendritic cell alpha interferon: implication for T-cell activation. Antimicrob Agents Chemother2014; $54: 871-881$.

109. Accapezzato D, Visco V, Francavilla V, et al. Chloroquine enhances human CD8+ T cell responses against soluble antigens in vivo. J Exp Med 2005; 202 :817-28.

110. Baize S, Leroy EM, Georges AJ, et al. Inflammatory responses in Ebola virus-infected patients. Clin Exp Immunol 2002;128:163-168.

111. Geisbert TW, Strong JE, Feldmann H. Considerations in the use of nonhuman primate models of Ebola virus and Marburg virus infection.J Infect Dis 2015; 212 :S91-97.

112. Yang Z, Delgado R, Xu L, et al. Distinct cellular interactions of secreted and transmembrane Ebola virus glycoproteins.Science 1998; 279 :1034-1027.

113. Tracey KJ, Cerami A. Tumor necrosis factor: a pleiotropic cytokine and therapeutic target. Annu Rev Med 1994; $45: 491-503$.

114. Schroder K, Hertzog PJ, Ravasi T, Hume DA. Interferon-gamma: an overview of signals, mechanisms and functions. J Leukoc Biol2004; 75 :163-189.

115. Routy JP, Angel JB, Patel M, et al. Assessment of chloroquine as a modulator of immune activation to improve CD4 recovery in immune nonresponding HIV-infected patients receiving antiretroviral therapy.HIV Med 2014; $16: 48-56$.

116. Leroux-Roels G, Bourguignon P, Willekens J, et al.Immunogenicity and safety of a booster dose of an investigational adjuvanted polyprotein HIV-1 vaccine in healthy adults and effect of administration of chloroquine. Clin Vaccine Immunol 2014;21 :302-311. 
117. Murray SM, Down CM, Boulware DR, et al. Reduction of immune activation with chloroquine therapy during chronic HIV infection.J Virol 2010; 84 :12082-12086.

118. Savarino A, Shytaj IL. Chloroquine and beyond: exploring anti-rheumatic drugs to reduce immune hyperactivation in HIV/AIDS.Retrovirology 2015; $12: 51$.

119. Chen L, Liu HG, Liu W, et al . Analysis of clinical features of 29 patients with 2019 novel coronavirus pneumonia. Zhonghua Jie He He Hu Xi Za Zhi 2020; 43 :E005.

120. Lianhan S, Jianping Z, Yi H, et al . On the use of corticosteroids for 2019-nCoV pneumonia. Lancet 2020 .

121. Strand V, Ahadieh S, French J, et al . Systematic review and meta-analysis of serious infections with tofacitinib and biologic disease-modifying antirheumatic drug treatment in rheumatoid arthritis clinical trials. Arthritis Res Ther 2015; $17: 362$.

122. Klumperman J, Locker JK, Meijer A, et al . Coronavirus M proteins accumulate in the Golgi complex beyond the site of virion budding. J Virol 1994; 68 :6523-34.

123. Wang PH, Cheng Y. Increasing host cellular receptor - angiotensin converting enzyme 2 (ACE2) expression by coronavirus may facilitate $2019 \mathrm{nCoV}$ infection. bioRxiv 2020; doi:10.1101/2020.02.24.963348.

124. Li R, Qiao S, Zhang G. Analysis of angiotensin-converting enzyme 2 (ACE2) from different species sheds some light on cross-species receptor usage of a novel coronavirus 2019-nCoV. J Infect 2020; doi:10.1016/j.jinf.2020.02.013.

125. Zhao Y, Zhao Z, Wang Y, et al . Single-cell RNA expression profiling of ACE2, the putative receptor of Wuhan 2019-nCov.bioRxiv 2020; doi:10.1101/2020.01.26.919985

126. Glowacka I, Bertram S, Müller MA, et al. Evidence that TMPRSS2 activates the severe acute respiratory syndrome coronavirus spike protein for membrane fusion and reduces viral control by the humoral immune response. J Virol 2011; 85 :4122-4134.

127. Yang ZY, Huang Y, Ganesh L, Leung K, Kong WP, Schwartz O, et al. pH-dependent entry of severe acute respiratory syndrome coronavirus is mediated by the spike glycoprotein and enhanced by dendritic cell transfer through DC-SIGN. J Virol 2004;78:5642-50. doi: 10.1128/JVI.78.11.5642-5650.2004.

128. Wang H, Yang P, Liu K, et al . SARS coronavirus entry into host cells through a novel clathrin- and caveolae independent endocytic pathway. Cell Res 2008; 18 :290-301. doi:10.1038/cr.2008.15.

129. Cassell S, Edwards J, Brown DT. Effects of lysosomotropic weak bases on infection of BHK-21 cells by Sindbis virus. J Virol 1984;52 :857-64.

130. Kwiek JJ, Haystead TA, Rudolph J. Kinetic mechanism of quinone oxidoreductase 2 and its inhibition by the antimalarial quinolines. Biochemistry 2004; $43: 4538-4547$.

131. Varki A. Sialic acids as ligands in recognition phenomena. FASEB J 1997; $11: 248-55$.

132. Olofsson S, Kumlin U, Dimock K, et al . Avian influenza and sialic acid receptors: more than meets the eye? Lancet Infect Dis 2005; 5 :184-8.

133. Zeng Q, Langereis MA, van Vliet ALW, et al . Structure of coronavirus hemagglutinin-esterase offers insight into corona and influenza virus evolution. Proc Natl Acad Sci USA 2008;105:9065-9.

134. Bakkers MJG, Lang Y, Feistsma LJ, et al . Betacoronavirus adaptation to humans involved progressive loss of hemagglutinin-esterase lectin activity. Cell Host Microbe 2017;21 :356-66. doi:10.1016/j.chom.2017.02.008.

135. Gautret P, Lagier J-C, Parola P, et al . Hydroxychloroquine and azithromycin as a treatment of COVID19: results of an open label non-randomized clinical trial. medRxiv 2020; doi:10.1101/2020.03.16.20037135.

136. De Clercq E. New nucleoside analogues for the treatment of hemorrhagic fever virus infections. Chem Asian $J$ 2019; $14: 3962-3968$.

137. Zumla, A. Chan JFW, Azhar EI et al . Coronaviruses-drug discovery and therapeutic options. Nat Rev Drug Discov 2016;15:327-347.

138. Zhou N, Pan T, Zhang J, et al . Glycopeptide antibiotics potently inhibit cathepsin L in the late endosome/lysosome and block the entry of Ebola virus, Middle East respiratory syndrome Coronavirus (MERS-CoV), and severe acute respiratory syndrome Coronavirus (SARS-CoV). J Biol Chem 2016;291 :9218-9232. doi:10.1074/jbc.M116.716100.

139. Colson P, Raoult D. Fighting viruses with antibiotics: an overlooked path. Int J Antimicrob Agents 2016; 48 :349-352. doi:10.1016/j.ijantimicag.2016.07.004. 
140. Baron SA, Christian Devaux, Philippe Colson, et al . Teicoplanin: an alternative drug for the treatment of coronavirus COVID-19?, Intl J Antimicrob Agents 2020; doi: 10.1016/j.ijantimicag.2020.105944

141. Zhang J, Ma X, Yu F, et al . Teicoplanin potently blocks the cell entry of 2019-nCoV. BioRxiv 2020; doi:10.1101/2020.02.05.935387.

142. Levy M, Buskila D, Gladman DD, et al . Pregnancy outcome following first trimester exposure to chloroquine. Am J Perinatol 1991; 8 :174-178.

143. Wilde De AH, Dirk J, Posthuma CC, et al . Screening of an FDA-approved compound library identifies four small-molecule inhibitors of Middle East respiratory syndrome coronavirus replication in cell culture. Antimicrob Agents Chemother 2014;58 : 4875.

144. Colson P, Rolain J-M, Raoult D. Chloroquine for the 2019 novel coronavirus SARSCoV-2. Int J Antimicrob Agents 2020;105923.

145. https://www.who.int/emergencies/diseases/novel-coronavirus-2019/situationreports/.(Accessed on 5th March 2020).

146. Frisk-Holmberg M, Bergqvist Y, Englund U. Chloroquine intoxication. Br J Clin Pharmacol 1983; 15 :502-503. doi:10.1111/j.1365-2125.1983.tb01540.x.

147. Zhou D, Dai S-M, Tong Q. COVID-19: a recommendation to examine the effect of hydroxychloroquine in preventing infection and progression.J Antimicrob Chemother 2020; doi:10.1093/jac/dkaa114

148. https://ci.rivm.nl/covid-19/bijlage/behandeladvies. (Accessed on 6th March 2020).

Table 1: Key unanticipated events in the history of repurposing CQ analogues ${ }^{\text {a }}$

\begin{tabular}{ll}
\hline Year & Discovery/ events \\
\hline Before 1532 & Indigenous Quina-quina bark is applied in South America to treat febrile illness \\
1632 & Quina-quina bark is used to treat for "tertian fever" in Peru \\
$1629-1633$ & The Romantic legend of Countess of Chinchon is cured with quina-quina bark \\
1633 & Jesuit priest Bernabe' de Cobo transported the bark from Peru to Europe (Spain) \\
$1600-1700$ & Quina-quina powder is distributed throughout Europe and Asia for febrile illness \\
1742 & Quina-quina tree is renamed as Cinchona tree by Carolus Linnaeus (botanist) \\
1818 & Quinine is isolated from cinchona tree bark for the treatment of malaria \\
1894 & Quinine is the first prescribed form to treat lupus by Dr. J.F. Payne \\
1908 & Nuclear structure of quinoline is indispensable for antimalarial activity. \\
1920 & The first synthetic antimalarial drug, pamaquine \\
1930 & Quinacrine is developed to treat malaria \\
1931 & Ehrlich group synthesized quinacrine \\
1934 & Hans Andersag synthesized resochin \\
1939 & Resochin is renamed as chloroquine \\
1940 & Quinacrine is used in Russia for lupus \\
World War II & The improvement of inflammatory diseases in British soldiers by quinacrine \\
1945 & HCQ is synthesized. Clinical trials in USA approved for human use \\
1946 & FDA-approved CQ for treatment of malaria \\
1951 & Effectiveness of quinacrine in the treatment of lupus \\
1955 & FDA-approved Plaquenil (HCQ sulfate) for SLE and CLE treatment. \\
1956 & Improvement of inflammation in RA patients by CQ \\
1959 & Triquin (HCQ, CQ and QC combination) is FDA-approved to treat lupus \\
1960 & Anticancer properties of CQ \\
1970 & As lysosomotropic agent, CQ is first shown to inhibit cell growth of tumour in vitro. \\
1970 & Banned clioquinol in response to controversy association with SMON in Japan \\
1972 & FDA-approved for Triquin withdrawn and is pulled off the market \\
1974 & CQ withdrawn from Japanese market claim as SMON and retinopathy \\
$1980-90$ & CQ analogs are investigated as autophagy inhibitors in vitro \\
1989 & The first reflection that CQ has an anti-cancer effect in Burkitt's lymphoma \\
1998 & The first observation that CQ is an autophagy inhibitor \\
&
\end{tabular}




\begin{tabular}{ll}
\hline Year & Discovery/ events \\
\hline 2000 & Anticancer properties of HCQ \\
2003 & First clinical trial of CQ for the antitumour effects of CQ in glioblastoma. \\
2007 & The synergistic effect CQ in combination with anticancer drugs \\
2009 & Debut of HCQ in Japan for clinical care \\
$2010-$ & CQ analogs in emerging viral infectious diseases (AIDS, SARS, Dengue) \\
$2014-$ & HCQ in clinical trials for selectively targeted autophagy in cancer patients \\
2017 & HCQ overcome anticancer drug resistances \\
$2019-2020$ & HCQ is used for the treatment of COVID-19 \\
\hline
\end{tabular}

Abbreviations: SLE: systemic lupus erythematosus; CLE: cutaneous lupus erythematosus; SMON: subacute myelo-optic neuropathy. QC: quinacrine.

${ }^{a}$ Major references ${ }^{39,88,89}$

Table 2: Activities of chloroquine analogues against coronaviruses

\begin{tabular}{|c|c|c|c|}
\hline Agents; Reference & Targeted virus & $\begin{array}{l}\text { System used for } \\
\text { antiviral activity } \\
\text { screening }\end{array}$ & Antiviral effect \\
\hline $\mathrm{CQ}^{46}$ & SARS-CoV & $\begin{array}{l}\text { Vero (African green } \\
\text { monkey kidney) E6 } \\
\text { cells }\end{array}$ & $\mathrm{EC}_{50}=8.8 \pm 1.2 \mu \mathrm{M}$ \\
\hline $\mathrm{CQ}^{111}$ & SARS-CoV & Vero E6 cells & $\mathrm{EC}_{50}=4.4 \pm 1.0 \mu \mathrm{M}$ \\
\hline \multirow[t]{2}{*}{$\mathrm{CQ}, \mathrm{CQ}-\mathrm{P}, \mathrm{CQ}-2 \mathrm{P}^{30}$} & SARS-CoV (four strains) & Vero 76 cells & $\begin{array}{l}\text { CQ: } \mathrm{EC}_{50}=1-4 \mu \mathrm{M} \\
\text { CQ-P: } \mathrm{EC}_{50}=4-6 \mu \mathrm{M} \\
\text { CQ-2P: } \mathrm{EC}_{50}=3-4 \mu \mathrm{M}\end{array}$ \\
\hline & & $\mathrm{BALB} / \mathrm{c}$ mice & $\begin{array}{l}\text { IP or IN CQ, starting } 4 \\
\mathrm{~h} \text { prior to virus } \\
\text { exposure: } 50 \mathrm{mg} / \mathrm{kg} \\
\text { but not } 10 \mathrm{mg} / \mathrm{kg} \text { or } 1 \\
\mathrm{mg} / \mathrm{kg} \text { reduced for the } \\
\text { IN route (but not the } \\
\text { IP route) viral lung } \\
\text { titres from mean } \pm \\
\text { S.D. of } 5.4 \pm 0.5 \text { to } 4.4 \\
\pm 1.2 \text { in } \log _{10} \\
\mathrm{CCID}_{50} / \mathrm{g} \text { at Day } 3\end{array}$ \\
\hline \multirow[t]{2}{*}{$\mathrm{CQ}, \mathrm{HCQ}^{30}$} & SARS-CoV & Vero cells & $\begin{array}{l}\mathrm{CQ}: \mathrm{EC}_{50}=6.5 \pm 3.2 \\
\mu \mathrm{M} H \mathrm{HCQ}: \mathrm{EC}_{50}=34 \pm \\
5 \mu \mathrm{M}\end{array}$ \\
\hline & Feline coronavirus & CRFK cells & $\begin{array}{l}\mathrm{CQ}: \mathrm{EC}_{50}>0.8 \mu \mathrm{M} \\
\mathrm{HCQ}: \mathrm{EC}_{50}=28 \pm 27 \\
\mu \mathrm{M}\end{array}$ \\
\hline $\mathrm{CQ}^{76}$ & $\mathrm{HCoV}-229 \mathrm{E}$ & $\begin{array}{l}\text { Human epithelial lung } \\
\text { cells (L132) }\end{array}$ & $\begin{array}{l}\mathrm{CQ} \text { at } 10 \mu \mathrm{M} \text { and } 25 \\
\mu \mathrm{M} \text { inhibited } \\
\mathrm{HCoV}-229 \mathrm{E} \text { release } \\
\text { into the culture } \\
\text { supernatant }\end{array}$ \\
\hline
\end{tabular}




\begin{tabular}{|c|c|c|c|}
\hline Agents; Reference & Targeted virus & $\begin{array}{l}\text { System used for } \\
\text { antiviral activity } \\
\text { screening }\end{array}$ & Antiviral effect \\
\hline$\overline{\mathrm{CQ}^{69}}$ & HCoV-OC43 & $\begin{array}{l}\text { HRT-18 cells New-born } \\
\text { C57BL/ } 6 \text { mice; CQ } \\
\text { administration TP and } \\
\text { via maternal milk }\end{array}$ & $\begin{array}{l}\mathrm{EC}_{50}=0.306 \pm 0.0091 \\
\mu \mathrm{M} 100 \%, 93 \%, 33 \% \text { and } \\
0 \% \text { survival rate of pups } \\
\text { when mother mice were } \\
\text { treated with } 15,5,1 \text { and } \\
0 \mathrm{mg} / \mathrm{kg} / \text { day body } \\
\text { weight, separately }\end{array}$ \\
\hline $\mathrm{CQ}^{30}$ & FIPV & $\begin{array}{l}\text { Felis catus whole } \\
\text { fetus- } 4 \text { cells }\end{array}$ & $\begin{array}{l}\text { Inhibition of FIPV } \\
\text { replication by CQ in } \\
\text { concentration } \\
\text { dependent }\end{array}$ \\
\hline $\mathrm{CQ}^{78}$ & $\begin{array}{l}\text { SARS-CoV MERS-CoV } \\
\text { HCoV-229E-GFP }\end{array}$ & $\begin{array}{l}\text { Vero E6 cells Huh7 cells } \\
\text { Huh7 cells }\end{array}$ & $\begin{array}{l}\text { EC } 50=4.1 \pm 1.0 \mu \mathrm{M} \\
\text { EC } 50=3.0 \pm 1.1 \mu \mathrm{M} \\
\text { EC } 50=3.3 \pm 1.2 \mu \mathrm{M}\end{array}$ \\
\hline $\mathrm{CQ}^{41}$ & SARS-CoV-2 & Vero E6 cells & $\mathrm{EC} 50=1.13 \mu \mathrm{M}$ \\
\hline
\end{tabular}

Abbreviations: CQ-P: Chloroquine monophosphate; CQ-2P: Chloroquine diphosphate; IP: Intraperitoneal; IN: Intranasal; TP: transplacentally; $\mathrm{CCID}_{50}: 50 \%$ cell culture infectious dose; CoV: coronavirus; $\mathrm{EC}_{50}$ : $50 \%$ effective concentration; GFP: Green fluorescent protein; HCoV: human coronavirus; MERS: Middle East respiratory syndrome; SARS: Severe acute respiratory syndrome; FIPV: Feline infectious peritonitis virus; CRFK: Crandell-Reese feline kidney; HCoV-229E-GFP: (GFP-expressing recombinant HCoV-229E).

Table 3: Selected examples of clinical trials of chloroquine analogues in patients with COVID19 in China ${ }^{a}$

\begin{tabular}{|c|c|c|c|c|}
\hline Study design & Intervention & $\begin{array}{l}\text { Comparison } \\
\operatorname{group}(\mathrm{s})\end{array}$ & $\begin{array}{l}\text { COVID-19 (n } \\
\text { patients) }\end{array}$ & $\begin{array}{l}\text { Primary } \\
\text { outcomes }\end{array}$ \\
\hline $\begin{array}{ll}\text { Recruiting } & \text { Recruiting } \\
\text { status } & \text { status }\end{array}$ & $\begin{array}{l}\text { Recruiting } \\
\text { status }\end{array}$ & $\begin{array}{l}\text { Recruiting } \\
\text { status }\end{array}$ & $\begin{array}{l}\text { Recruiting } \\
\text { status }\end{array}$ & $\begin{array}{l}\text { Recruiting } \\
\text { status }\end{array}$ \\
\hline $\begin{array}{c}\text { ChiCTR2000030031Single Centre; } \\
\text { RCT }\end{array}$ & CQ-P; BID & Placebo; BID & $\begin{array}{l}\text { Mild and } \\
\text { common } \\
\text { pneumonia }(\mathrm{n}= \\
120)\end{array}$ & $\begin{array}{l}\text { Time of } \\
\text { conversion to be } \\
\text { negative of novel } \\
\text { coronavirus } \\
\text { nucleic acid }\end{array}$ \\
\hline $\begin{array}{c}\text { ChiCTR2000029988Single Centre; } \\
\text { RCT }\end{array}$ & CQ-P & $\begin{array}{l}\text { Standard } \\
\text { treatment }\end{array}$ & $\begin{array}{l}\text { Severe } \\
\text { pneumonia (n } \\
=80)\end{array}$ & $\begin{array}{l}\text { Time to } \\
\text { clinical } \\
\text { recovery }\end{array}$ \\
\hline $\begin{array}{c}\text { ChiCTR2000029899Single Centre; } \\
\text { RCT }\end{array}$ & $\begin{array}{l}\text { HCQ: Day } 1: 1^{\text {st }} \\
\text { dose: } 6 \text { Tab }(0.1 \\
\text { g/Tab), } 2^{\text {nd }} \\
\text { dose: } 6 \text { Tab }(0.1 \\
\text { g/Tab) after } 6 \text { h; } \\
\text { Day 2-10: } 2 \\
\text { Tab/day }(0.1 \\
\text { g/Tab) }\end{array}$ & $\begin{array}{l}\text { CQ-P: Day 1-3: } \\
500 \mathrm{mg}, \mathrm{BID}, \\
\text { Day 4-10: } 250 \\
\text { mg BID }\end{array}$ & $\begin{array}{l}\text { Mild and } \\
\text { common } \\
\text { Pneumonia }(\mathrm{n}= \\
100)\end{array}$ & $\begin{array}{l}\text { Time to clinical } \\
\text { recovery }\end{array}$ \\
\hline
\end{tabular}




\begin{tabular}{|c|c|c|c|c|}
\hline Study design & Intervention & $\begin{array}{l}\text { Comparison } \\
\operatorname{group}(\mathrm{s})\end{array}$ & $\begin{array}{l}\text { COVID-19 (n } \\
\text { patients) }\end{array}$ & $\begin{array}{l}\text { Primary } \\
\text { outcomes }\end{array}$ \\
\hline $\begin{array}{c}\text { ChiCTR2000029898Single Centre; } \\
\text { RCT }\end{array}$ & $\begin{array}{l}\text { HCQ; Day1: } 1^{\text {st }} \\
\text { dose: } 6 \text { Tab }(0.1 \\
\text { g/Tab), } 2^{\text {nd }} \\
\text { dose: } 6 \text { Tab } \\
\text { (0.1g/Tab) after } \\
6 \text { h; Day } 2^{\sim} 10: 2 \\
\text { Tab/day } \\
\text { (0.1g/Tab) }\end{array}$ & $\begin{array}{l}\text { CQ-P; Day 1-3: } \\
500 \text { mg BID; } \\
\text { Day 4-10: } 250 \\
\text { mg BID }\end{array}$ & $\begin{array}{l}\text { Severe } \\
\text { pneumonia }(\mathrm{n}= \\
100)\end{array}$ & $\begin{array}{l}\text { Time to clinical } \\
\text { improvement }\end{array}$ \\
\hline $\begin{array}{c}\text { ChiCTR2000029939Single Centre; } \\
\text { RCT }\end{array}$ & CQ-P & $\begin{array}{l}\text { Standard } \\
\text { treatment }\end{array}$ & $\begin{array}{l}\text { Pneumonia ( } \mathrm{n} \\
=100)\end{array}$ & $\begin{array}{l}\text { Length of } \\
\text { hospital stay }\end{array}$ \\
\hline ChiCTR2000029935Single Centre & CQ-P & $\begin{array}{l}\text { No comparison } \\
\text { group }\end{array}$ & $\begin{array}{l}\text { Pneumonia (n } \\
=100)\end{array}$ & $\begin{array}{l}\text { Length of } \\
\text { hospital stay }\end{array}$ \\
\hline $\begin{array}{c}\text { ChiCTR2000029868Multi-Centre; } \\
\text { RCT }\end{array}$ & $\begin{array}{l}\text { Oral HCQ-S } \\
\text { Tab }\end{array}$ & $\begin{array}{l}\text { Standard } \\
\text { treatment }\end{array}$ & $\begin{array}{l}\text { Pneumonia (n } \\
=200)\end{array}$ & $\begin{array}{l}\text { Viral nucleic } \\
\text { acid test }\end{array}$ \\
\hline $\begin{array}{c}\text { ChiCTR2000029761Multi-Centre; } \\
\text { RCT }\end{array}$ & $\begin{array}{l}\text { Low-dose HCQ } \\
\text { group } \\
\text { Medium-dose } \\
\text { HCQ group; } \\
\text { High-dose HCQ } \\
\text { group }\end{array}$ & $\begin{array}{l}\text { Standard } \\
\text { treatment }\end{array}$ & $\begin{array}{l}\text { Common } \\
\text { pneumonia }(\mathrm{n}= \\
240)\end{array}$ & $\begin{array}{l}\text { Negative } \\
\text { conversion rate } \\
\text { of COVID-19 } \\
\text { nucleic acid; } \\
\text { lung } \\
\text { inflammation } \\
\text { absorption ratio }\end{array}$ \\
\hline $\begin{array}{c}\text { ChiCTR2000029741Multi-Centre; } \\
\text { RCT }\end{array}$ & CQ-P & \multicolumn{2}{|c|}{$\begin{array}{l}\text { Lopinavir/RitonavirMild and } \\
\text { common } \\
\text { Pneumonia }(\mathrm{n}= \\
112)\end{array}$} & $\begin{array}{l}\text { All-cause } \\
\text { mortality at day } \\
28 ; \text { length of stay }\end{array}$ \\
\hline $\begin{array}{c}\text { ChiCTR2000029740Single Centre; } \\
\text { RCT }\end{array}$ & $\begin{array}{l}\text { Oral HCQ; } 0.2 \mathrm{~g} \\
\text { BID }\end{array}$ & $\begin{array}{l}\text { Standard } \\
\text { treatment }\end{array}$ & $\begin{array}{l}\text { Pneumonia }(\mathrm{n}= \\
78)\end{array}$ & $\begin{array}{l}\text { Negative } \\
\text { conversion rate } \\
\text { of COVID-19 } \\
\text { nucleic acid }\end{array}$ \\
\hline $\begin{array}{c}\text { ChiCTR2000029542Single Centre; } \\
\text { PCS }\end{array}$ & $\begin{array}{l}\text { Oral CQ; } 0.5 \mathrm{~g} \\
\text { BID for } 10 \text { days }\end{array}$ & $\begin{array}{l}\text { Standard } \\
\text { treatment }\end{array}$ & $\begin{array}{l}\text { Pneumonia }(\mathrm{n}= \\
20)\end{array}$ & $\begin{array}{l}\text { Negative } \\
\text { conversion rate } \\
\text { of COVID-19 } \\
\text { nucleic acid; } \\
\text { 30-day cause } \\
\text { specific mortality }\end{array}$ \\
\hline $\begin{array}{c}\text { ChiCTR2000029559Single Centre; } \\
\text { RCT }\end{array}$ & $\begin{array}{l}\text { Group 1: oral } \\
\text { HCQ; 0.1 g BID; } \\
\text { Group 2: oral } \\
\text { HCQ; } 0.2 \text { g BID }\end{array}$ & $\begin{array}{l}\text { Placebo: Oral } \\
\text { starch pill BID }\end{array}$ & $\begin{array}{l}\text { Pneumonia }(\mathrm{n}= \\
300)\end{array}$ & $\begin{array}{l}\text { Negative } \\
\text { conversion rate } \\
\text { of COVID-19 } \\
\text { nucleic acid; T } \\
\text { cell recovery } \\
\text { time }\end{array}$ \\
\hline $\begin{array}{c}\text { ChiCTR2000029762Single Centre; } \\
\text { RCT }\end{array}$ & HCQ Tab & $\begin{array}{l}\text { Standard } \\
\text { treatment }\end{array}$ & $\begin{array}{l}\text { Pneumonia }(\mathrm{n}= \\
60)\end{array}$ & $\begin{array}{l}\text { Negative } \\
\text { conversion rate } \\
\text { of COVID-19 } \\
\text { nucleic acid; } \\
\text { lung } \\
\text { inflammation } \\
\text { absorption ratio }\end{array}$ \\
\hline
\end{tabular}




\begin{tabular}{|c|c|c|c|c|}
\hline Study design & Intervention & $\begin{array}{l}\text { Comparison } \\
\text { group(s) }\end{array}$ & $\begin{array}{l}\text { COVID-19 (n } \\
\text { patients) }\end{array}$ & $\begin{array}{l}\text { Primary } \\
\text { outcomes }\end{array}$ \\
\hline $\begin{array}{ll}\text { Pending } & \text { Pending } \\
\text { approval status } & \text { approval status }\end{array}$ & $\begin{array}{l}\text { Pending } \\
\text { approval status }\end{array}$ & $\begin{array}{l}\text { Pending } \\
\text { approval status }\end{array}$ & $\begin{array}{l}\text { Pending } \\
\text { approval status }\end{array}$ & $\begin{array}{l}\text { Pending } \\
\text { approval status }\end{array}$ \\
\hline $\begin{array}{c}\text { ChiCTR2000029609Multi-Centre; } \\
\text { Non-RCT }\end{array}$ & $\begin{array}{l}\text { Mild-moderate } \\
\text { CQ group: oral } \\
\text { CQ-P; } \\
\text { Mild-moderate } \\
\text { combination } \\
\text { group: CQ-P } \\
\text { plus Lop/Rit; } \\
\text { Severe CQ } \\
\text { group: oral } \\
\text { CQ-P }\end{array}$ & $\begin{array}{l}\text { Mild-moderate } \\
\text { Lop/Rit group: } \\
\text { oral Lop/Rit; } \\
\text { Severe Lop/Rit } \\
\text { group: oral } \\
\text { Lop/Rit }\end{array}$ & $\begin{array}{l}\text { Pneumonia }(\mathrm{n}= \\
205)\end{array}$ & $\begin{array}{l}\text { Negative } \\
\text { conversion rate } \\
\text { of COVID-19 } \\
\text { nucleic acid }\end{array}$ \\
\hline $\begin{array}{c}\text { ChiCTR2000030054Single Centre } \\
\text { RCT }\end{array}$ & $\begin{array}{l}\text { HCQ-S group: } \\
\text { HCQ-S } 0.2 \mathrm{~g} \\
\text { BID x } 14 \text { days; } \\
\text { CQ-P group: } \\
1^{\text {st }} \text { dose of } \\
\text { CQ-P } 1 \mathrm{~g} \times 2 \\
\text { days, then } 0.5 \\
\text { g x } 12 \text { days }\end{array}$ & $\begin{array}{l}\text { Standard } \\
\text { treatment }\end{array}$ & $\begin{array}{l}\text { Mild and } \\
\text { common } \\
\text { pneumonia (n } \\
=100)\end{array}$ & $\begin{array}{l}\text { Clinical } \\
\text { recovery time }\end{array}$ \\
\hline $\begin{array}{c}\text { ChiCTR2000029992Single Centre } \\
\text { RCT }\end{array}$ & $\begin{array}{l}\text { CQ-P group: } \\
\text { CQ-P } 1.0 \mathrm{~g} \text { x } 2 \\
\text { days, then } 0.5 \mathrm{~g} \\
\text { x } 12 \text { day from } \\
\text { the third day } \\
\text { HCQ-S group: } \\
\text { HCQ-S } 0.2 \mathrm{~g} \\
\text { BID x } 14 \text { days }\end{array}$ & $\begin{array}{l}\text { Standard } \\
\text { treatment }\end{array}$ & $\begin{array}{l}\text { Severe } \\
\text { pneumonia }(\mathrm{n}= \\
100)\end{array}$ & $\begin{array}{l}\text { Clinical recovery } \\
\text { time; Changes in } \\
\text { viral load of } \\
\text { whole } \\
\text { respiratory tract } \\
\text { samples } \\
\text { compared with } \\
\text { the baseline }\end{array}$ \\
\hline $\begin{array}{r}\text { ChiCTR2000029975Single Centre; } \\
\text { Single-arm }\end{array}$ & $\begin{array}{l}150 \mathrm{mg} \text { CQ-P in } \\
5 \mathrm{ml} \text { of normal } \\
\text { saline, inhaled } \\
\text { by atomization } \\
\text { for one week }\end{array}$ & $\begin{array}{l}\text { No comparison } \\
\text { group }\end{array}$ & $\begin{array}{l}\text { Pneumonia }(\mathrm{n}= \\
\text { 10) }\end{array}$ & $\begin{array}{l}\text { Viral negative- } \\
\text { transforming } \\
\text { time; Time from } \\
\text { severe and } \\
\text { critical patients } \\
\text { to clinical } \\
\text { improvement }\end{array}$ \\
\hline $\begin{array}{c}\text { ChiCTR2000029803Single Centre; } \\
\text { RCT }\end{array}$ & $\begin{array}{l}\text { Group A1: } \\
\text { HCQ, small } \\
\text { dose; Group A2: } \\
\text { HCQ, high dose }\end{array}$ & $\begin{array}{l}\text { Group B1: } \\
\text { Arb-HCl low } \\
\text { dose; Group B2: } \\
\text { Arb-HCl high } \\
\text { dose }\end{array}$ & $\begin{array}{l}\text { Positive test of } \\
\text { COVID-19 } \\
\text { nucleic acid }(\mathrm{n}= \\
320)\end{array}$ & $\begin{array}{l}\text { Progression to } \\
\text { suspected or } \\
\text { confirmed } \\
\text { disease within } 24 \\
\text { days }\end{array}$ \\
\hline $\begin{array}{c}\text { ChiCTR2000029826Single Centre; } \\
\text { RCT }\end{array}$ & $\begin{array}{l}2 \text { Tab CQ-P; } \\
\text { BID }\end{array}$ & $\begin{array}{l}2 \text { Tab placebo; } \\
\text { BID }\end{array}$ & $\begin{array}{l}\text { Critically ill } \\
\text { pneumonia }(\mathrm{n} \\
=45)\end{array}$ & Mortality rate \\
\hline $\begin{array}{c}\text { ChiCTR2000029837Single Centre; } \\
\text { RCT }\end{array}$ & $\begin{array}{l}2 \text { Tab CQ-P; } \\
\text { BID }\end{array}$ & $\begin{array}{l}2 \text { Tab placebo; } \\
\text { BID }\end{array}$ & $\begin{array}{l}\text { Mild and } \\
\text { common } \\
\text { Pneumonia }(\mathrm{n}= \\
120)\end{array}$ & $\begin{array}{l}\text { Negative } \\
\text { conversion rate } \\
\text { of COVID-19 } \\
\text { nucleic acid }\end{array}$ \\
\hline
\end{tabular}




\begin{tabular}{|c|c|c|c|c|c|}
\hline Trial ID & Study design & Intervention & $\begin{array}{l}\text { Comparison } \\
\text { group(s) }\end{array}$ & $\begin{array}{l}\text { COVID-19 (n } \\
\text { patients) }\end{array}$ & $\begin{array}{l}\text { Primary } \\
\text { outcomes }\end{array}$ \\
\hline $\begin{array}{l}\text { Not yet } \\
\text { recruiting } \\
\text { status }\end{array}$ & $\begin{array}{l}\text { Not yet } \\
\text { recruiting } \\
\text { status }\end{array}$ & $\begin{array}{l}\text { Not yet } \\
\text { recruiting } \\
\text { status }\end{array}$ & $\begin{array}{l}\text { Not yet } \\
\text { recruiting } \\
\text { status }\end{array}$ & $\begin{array}{l}\text { Not yet } \\
\text { recruiting } \\
\text { status }\end{array}$ & $\begin{array}{l}\text { Not yet } \\
\text { recruiting } \\
\text { status }\end{array}$ \\
\hline ChiCTR2000030 & $\begin{array}{l}\text { 7Single Centre; } \\
\text { RCT }\end{array}$ & $\begin{array}{l}\text { CQ-P } \\
\text { aerosolized } \\
\text { inhalation }\end{array}$ & $\begin{array}{l}\text { WFI atomized } \\
\text { inhale combined }\end{array}$ & $\begin{array}{l}\text { Pneumonia }(\mathrm{n}= \\
30)\end{array}$ & $\begin{array}{l}\text { Temperature } \\
\text { normal for more } \\
\text { than } 3 \text { days, } \\
\text { respiratory } \\
\text { symptoms }\end{array}$ \\
\hline NCT04261517 & $\begin{array}{l}\text { Single Centre; } \\
\text { RCT }\end{array}$ & $\begin{array}{l}\mathrm{HCQ} 400 \\
\mathrm{mg} / \text { day for } 5 \\
\text { days }\end{array}$ & $\begin{array}{l}\text { Standard } \\
\text { treatment }\end{array}$ & $\begin{array}{l}\text { Pneumonia (n } \\
=30)\end{array}$ & $\begin{array}{l}\text { Mortality rate } \\
\text { at day } 14\end{array}$ \\
\hline NCT04286503 & $\begin{array}{l}\text { Multi-Centre; } \\
\text { RCT }\end{array}$ & Carrimycin & $\begin{array}{l}\text { Lop/Rit; or Arb } \\
\text { or CQ-P }\end{array}$ & $\begin{array}{l}\text { Critically ill } \\
\text { pneumonia }(\mathrm{n}= \\
520)\end{array}$ & $\begin{array}{l}\text { Fever to normal } \\
\text { time; pulmonary } \\
\text { inflammation } \\
\text { resolution time } \\
\text { at } 30 \text { day }\end{array}$ \\
\hline
\end{tabular}

Abbreviations: BID: twice per day; RCT: Randomized controlled trial; PCS: Prospective cohort study; CQ-P: Chloroquine phosphate; HCQ: Hydroxychloroquine; HCQ-S: Hydroxychloroquine sulphate; Lop/Rit: Lopinavir/ritonavir; Arb-HCl: Arbidol hydrochloride; Tab: Tablets; $1^{\text {st }}:$ First; $2^{\text {nd }}:$ Second; WFI: Water for injection.

${ }^{\text {a Adapted from }}{ }^{24}$

Figure legends:

Figure 1. An overview of inhibition of autophagy process and repurposing CQ analogue development Figure 1a: Inhibition of autophagy by CQ

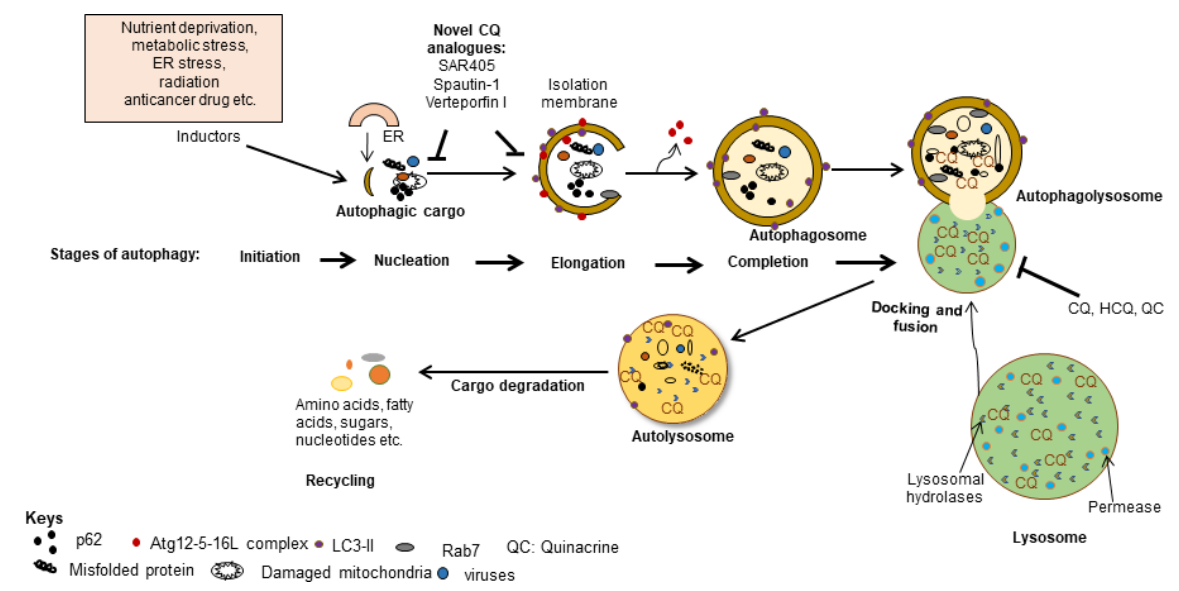

Figure 1b. Repurposing CQ analogue development 


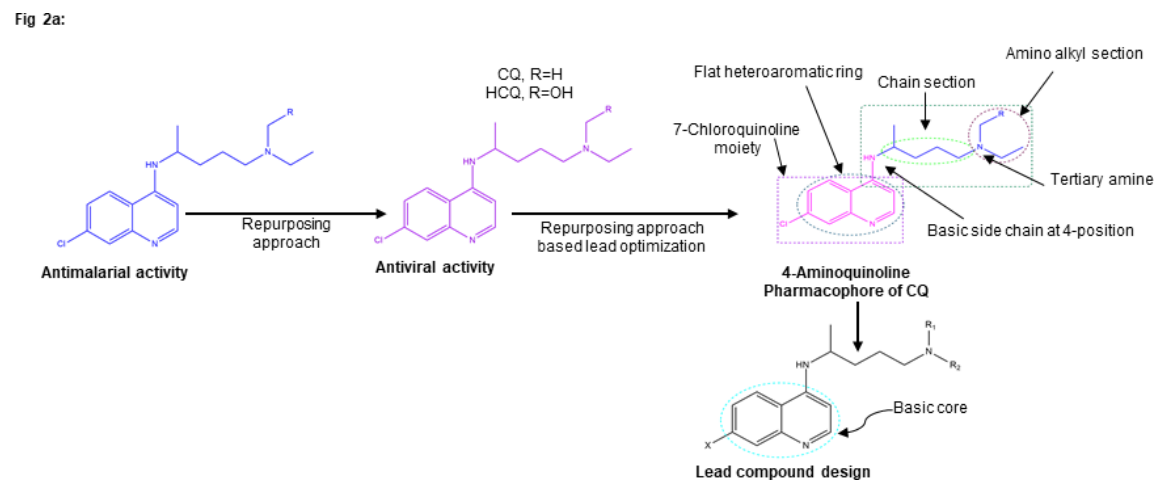

Figure 2. Lysosomotrophic and immunomodulating effects of CQ analogue on SARS-CoV-2 replication cycle Figure 2a. Lysosomotrophic effect of CQ

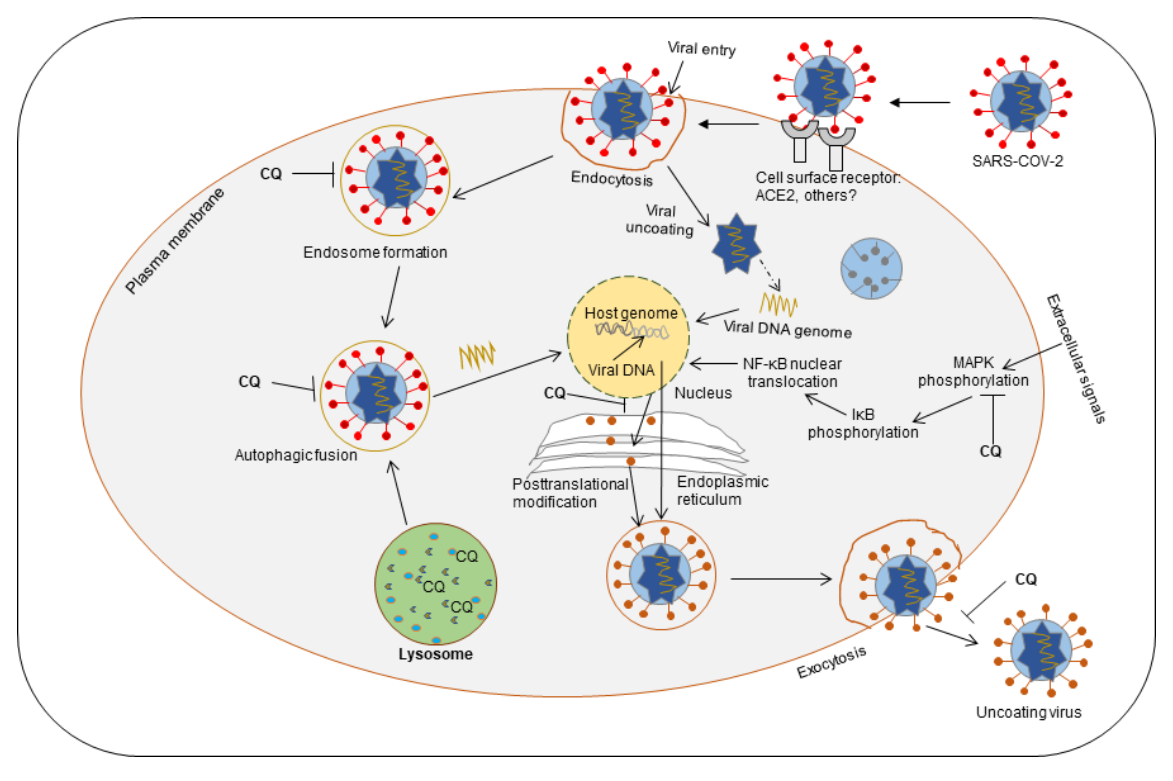

Figure 2b. immunomodulating effects of CQ 


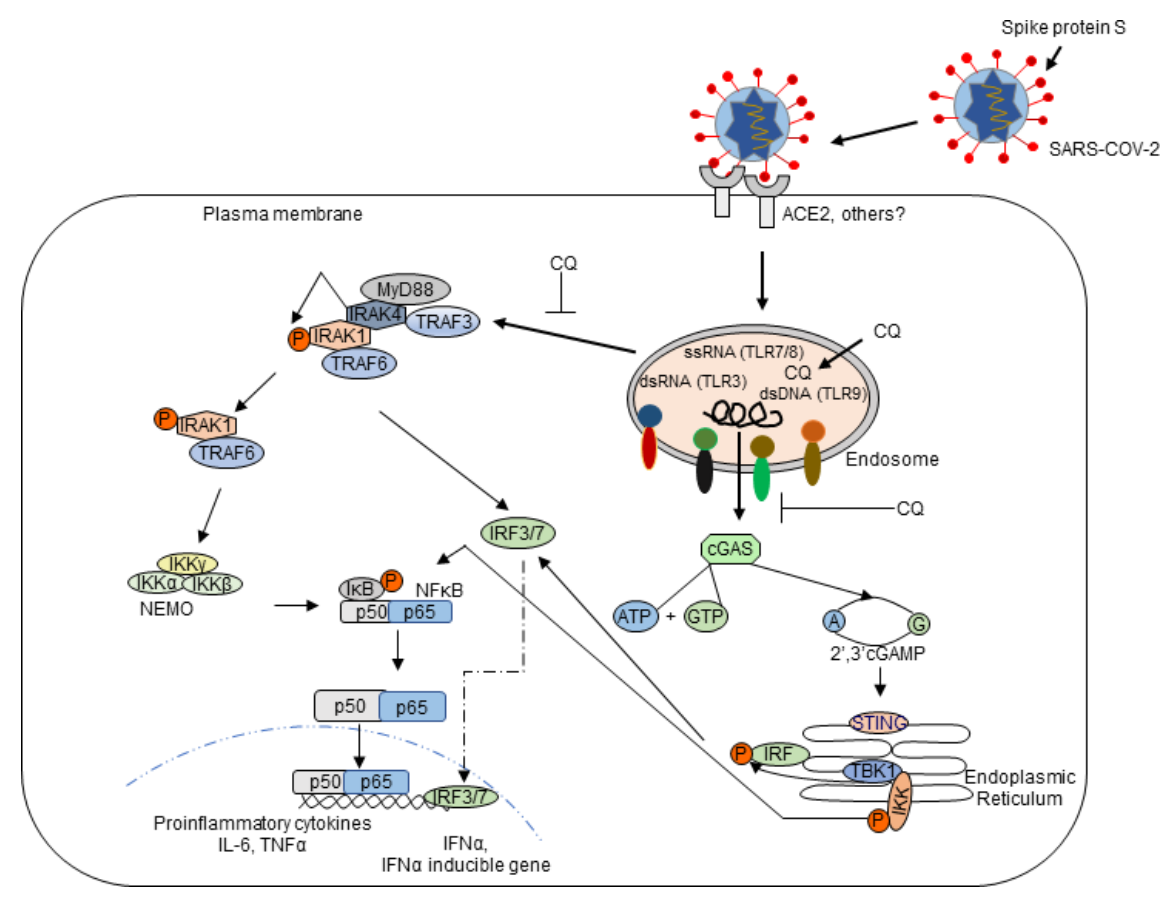

CQ becomes highly concentrated in such acidic organelles such as lysosome leading to dysfunction of several enzymes, e.g. those required for proteolytic processing and post-translational modification of viral proteins. CQ inhibits both TLR signalling and cGAS stimulation of interferon (IFN) genes (STING) pathway. Reverse transcription intermediates from $\mathrm{CoV}$ is recognized by cGAS, which catalyzes the production of cGAMP to bind and activate the ER-resident adaptor protein STING. STING then forms a complex with TBK1 and translocates from the ER to the perinuclear lysosomal compartments via an autophagy-like process. The STING-TBK1 complex subsequently activates transcription factors IRF3 and NF- $x \mathrm{~B}$ to induce the production of type I IFNs and inflammatory cytokines to establish an antiviral state. cGAMP: cyclic GMPAMP; cGAS: cyclic GMP-AMP synthase; IFN: interferon; IRF3: interferon regulatory factor 3; TRAF3: TNF receptor-associated receptor 3; TRAF6:TNF receptor-associated receptor 6; NF- $x$ B: nuclear factor- $x$ B; P: phosphorylation; STING: stimulator of interferon genes; TBK1: TANK binding kinase 1. 